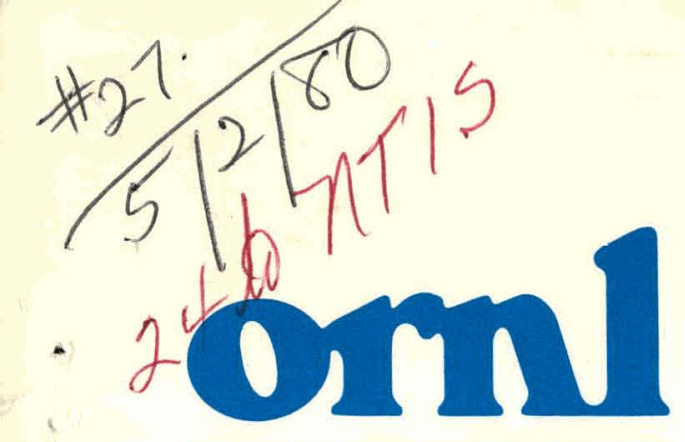

OAK

RIDGE

NATIONAL

LABORATORY

\section{UNION \\ CARBIDE}

\section{MASTER}

\title{
ACFAC-A Cash Flow Analysis Code for Estimating Product Price from an Industrial Operation
}

J. G. Delene

OPERATED BY

UNION CARBIDE CORPORATION FOR THE UNITED STATES DEPARTMENT OF ENERGY 


\section{DISCLAIMER}

This report was prepared as an account of work sponsored by an agency of the United States Government. Neither the United States Government nor any agency Thereof, nor any of their employees, makes any warranty, express or implied, or assumes any legal liability or responsibility for the accuracy, completeness, or usefulness of any information, apparatus, product, or process disclosed, or represents that its use would not infringe privately owned rights. Reference herein to any specific commercial product, process, or service by trade name, trademark, manufacturer, or otherwise does not necessarily constitute or imply its endorsement, recommendation, or favoring by the United States Government or any agency thereof. The views and opinions of authors expressed herein do not necessarily state or reflect those of the United States Government or any agency thereof. 


\section{DISCLAIMER}

Portions of this document may be illegible in electronic image products. Images are produced from the best available original document. 
Printed in the United States of America. Available from National Technical Information Service

U.S. Department of Commerce

5285 Port Royal Road, Springfield, Virginia 22161

NTIS price codes-Printed Copy: A04; Microfiche A01

This report was prepared as an account of work sponsored by an agency of the United States Government. Neither the United States Government nor any agency thereof, nor any of their employees, makes any warranty, express or implied, or assumes any legal liability or responsibility for the accuracy, completeness, or usefulness of any information, apparatus, product, or process disclosed, or represents that its use would not infringe privately owned rights. Reference herein to any specific commercial product, process, or service by trade name, trademark, manufacturer, or otherwise, does not necessarily constitute or imply its endorsement, recommendation, or favoring by the United States Government or any agency thereof. The views and opinions of authors expressed herein do not necessarily state or refloct those of the United States Government $\curvearrowright r$ any agency thereof. 
ORNL/TM-7150

Dist. Category UC-80

Contract No. W-7405-eng-26

Engineering Technology Division

\section{ACFAC - A CASH FLOW ANALYSIS CODE FOR ESTIMATING \\ PRODUCT PRICE FROM AN INDUSTRIAL OPERATION}

J. G. Delene

Date Published - April 1980

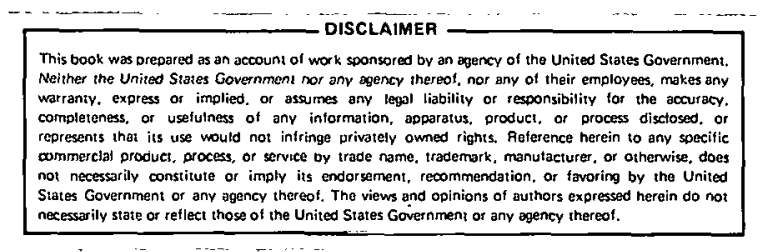

Prepared by the OAK RIDGE NATIONAL LABORATORY

Oak Ridge, Tennessee 37830

operated by

UNION CARBIDE CORPORATION

for the

DEPARTMEN'I' OF' E'NERGY

MOTBIBUTHOH OF THIS DOCUMENT IS URLIPAITE 
THIS PAGE

WAS INTENTIONALLY

LEFT BLANK 


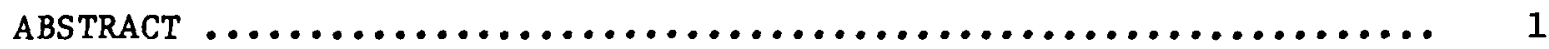

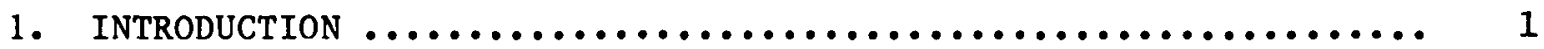

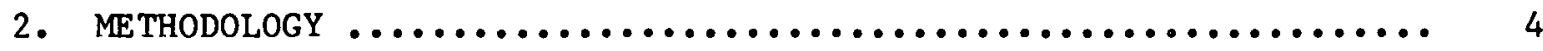

2.1 Discounted Cash Flow Method ...................... 4

2.2 Special Cons1derations ......................... 6

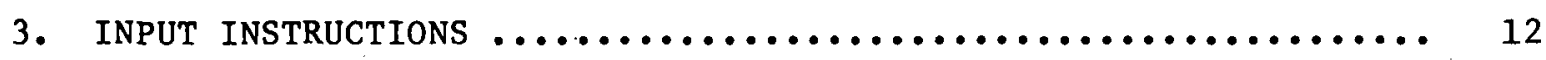

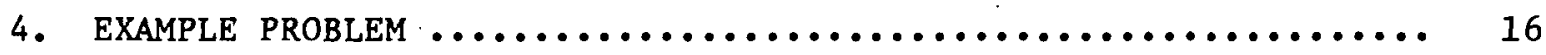

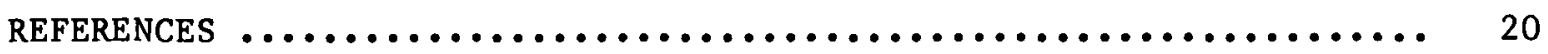

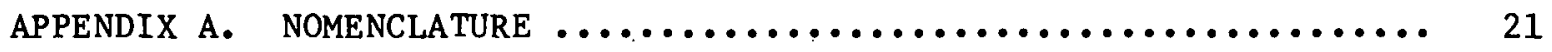

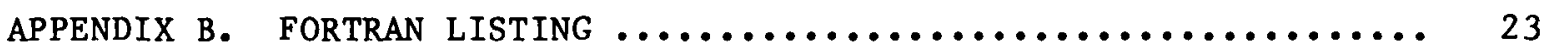

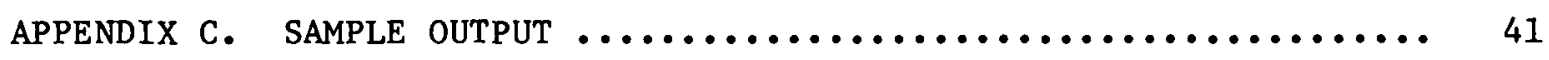




\title{
ACFAC - A CASH FLOW ANALYSIS CODE FOR ESTIMATING PRODUCT PRICE FROM AN INDUSTRIAL OPERATION
}

\author{
J. G. Delene
}

\section{ABSTRACT}

A computer code is presented which uses a discounted cash flow methodology to obtain an average product price for an industrial process. The general discounted cash flow method is discussed. Special code options include multiple treatments of interest during construction and other preoperational costs, investment tax credits, and different methods for tax depreciation of capital assets. Two options for allocating the cost of plant decommissioning are available.

The FORTRAN code listing and the computer output for a sample problem are included.

\section{INTRODUCTION}

The computer program ACFAC* was originally written to calculate weighted-average (or levelized) nuclear fuel fabrication and reprocessing unit costs. These costs, in units of dollars per kilogram of heavy metal, were to be used in a comparative economic analysis of alternative nuclear fuel systems. An example of the use of this code to estimate the fabrication cost of low-enriched uranium fuel for pressurized-water reactors is given in Ref. 1 .

The ACFAC code uses discounted cash flow techniques to obtain a levelized average cost of product in dollars per unit of product. The discounted cash flow approach is widely used by industry to evaluate alternative investments. The method is used here to obtain a constant unit price such that the revenue received from the sale of product throughout the life of the project (e.g., fuel fabrication plant) will pay a11 expenses, taxes, and return on outstanding capital investment and will pay back the investment by the end of the plant life. ACFAC

*ACFAC - A Cash Flow Analysis Code. 
is useful for obtaining consistent sets of unit costs for use in comparative analyses or for comparing alternative methods of producing a similar product.

The ACFAC program produces a single, constant, levelized unit cost. In reality, the unit cost may not be constant over the plant $11 \mathrm{fe}$. However, the present worth of the income produced by this unit cost is equal to that produced by the incomes obtained by the actual string of unequal unit costs. Al so, note that the unit cost calculated by ACFAC is not market price; market price results from market action and will not necessar$11 \mathrm{y}$ be the same as the cost estimate.

In addition to the single unit cost, a breakdown of this cost by cost component is given. A period-by-period cash flow table is also given in the output.

The ACFAC code has considerable flexibility in its treatment of capital investments, construction money, tax depreciation methods, expenses, and capital structure. Provisions are made for preoperational costs, investment tax credits, federal and state income taxes, property taxes and Insurance, Interim equipment replacement, materials costs, and tax loss carry forward.

Interest on construction money may be capitalized or expensed. There may be multiple groupings of capital investments, with each having its own construction schedule and in-service date. The plant's on-line capacity factor and the operating costs may vary with time. The code user can input the desired corporate financial structure and desired or expected returns on equity and debt capital.

The ACFAC code is similar to the PRP code, ${ }^{2}$ which was developed independently by Royes Salmon and used in the Department of Energy's coal programs. The two computer codes have features in common but are different in several ways; thus, a user of ACFAC should be aware of PRP and vice versa. For example, ACFAC will not estimate the rate of return for a set product price, but PRP is not as flexible in its treatments of capital investments. ACFAC has been used to calculate the example problem in the PRP report. The result is within $0.2 \%$ of that obtained with the PRP code. The difference results because ACFAC treats property tax as a deductible expense for state income tax purposes; it is not deducted in PRP. 
A FORTRAN 1isting of ACFAC is given as Appendix B to this report. ACFAC, programmed in FORTRAN IV, 1s designed to run on IBM 360 series computers. The program uses $120 \mathrm{~K}$ bytes of core during execution, and the running time for a typical case is about $0.4 \mathrm{~s}$. 


\section{METHODOLOGY}

\subsection{Discounted Cash Flow Method}

The objective of the calculations performed by this code is to obtain an average unit product price such that the revenue received from the sale of a product throughout the life of the project will pay all expenses, taxes, and return on outstanding investment and will pay off the investment by the end of the project life. The method used to estimate the product price is a form of the discounted cash flow method.

Simply stated, in the discounted cash flow method, the sum of all cash payments and receipts discounted at the average cost of money to some common point in time (usually the beginning of the project) is equal to zero, or

$$
\sum \frac{(\operatorname{cash} f l o w)_{n}}{(1+d)^{n}}=0
$$

$\mathbf{n}$

(See Appendix A for a description of nomenclature.)

The cash flow consists of the difference between the money received for the sale of product $\left(I_{n}\right)$ and all payments for capital investment $\left(Z_{n}\right)$ and operating expenses $\left(O_{n}\right)$. Another way of stating this equation is that the discounted cash receipts equal the discounted cash payments, or

$$
\sum_{n} \frac{I_{n}}{(1+d)^{n}}=\sum_{n} \frac{z_{n}+o_{n}}{(1+d)^{n}} .
$$

The revenue (or income) is equal to the price times the production rate, or

$$
I_{n}=s_{n}\left(P_{n}\right)
$$


If the product price $P$ is constant, then

$$
P=\frac{\sum_{n} \frac{z_{n}+o_{n}}{(1+d)^{n}}}{\sum_{n} \frac{s_{n}}{(1+d)^{n}}}
$$

The average cost of money or discount rate $d$ is the weighted-average cost of debt and equity capital based on the capital structure of the enterprise; thus,

$$
\mathrm{d}=\mathrm{F}_{\mathrm{b}^{\mathbf{i}_{\mathrm{b}}}}+\mathrm{F}_{\mathrm{e}^{\mathbf{i}_{\mathrm{e}}}}
$$

Use of this method assumes that the cost of money does not vary over the life of the project and that capital is retired or paid back in proportion to the original capitalization.

If the product price is to reflect all costs of production, all expenses must be included, including income taxes.

Income taxes complicate the direct computation of product price using Eq. (4). Income taxes depend on earnings, which, in turn, depend on the difference between income $\left[P\left(S_{n}\right)\right]$ and the deductible expenses during a tax period. These taxes are not easily estimated. Vondy ${ }^{3}$ and others ${ }^{4}$ have shown that an analytic equation exists which yields identical results to the standard cash flow equation but removes the direct calculation of income taxes from the expression. This equation is

$$
\begin{aligned}
& \left(\frac{1}{1-r}\right) \sum_{n} \frac{z_{n}}{(1+x)^{n}}+\sum_{n} \frac{o_{n}^{-}}{(1+x)^{n}}+\left(\frac{r}{1-r}\right) \sum_{n} \frac{D_{n}^{T}}{(1+x)^{n}} \\
& \mathrm{P}=
\end{aligned}
$$

In this expression, $O_{n}$ is the operating costs excluding income taxes, $r$ is the income tax rate, $D_{n}^{T}$ is the tax-deductible depreciation during period $n$, and $X$ is the tax-adjusted discount rate. This discount rate embodies the fact that interest on debt is deductible for income tax 
purposes; that is,

$$
X=(1-r) F_{b} i_{b}+F_{e} i_{e}
$$

The product price calculated using Eq. (6) will satisfy the requirements stated in the first paragraph of this section and produce a unit price identical with that obtained from Eq. (4) in most cases. There is an implicit assumption in this method that tax losses (negative income taxes) are used to offset other corporate income taxes and are not carried forward or lost al together.

In the computer code, the product price is obtained by an 1terative solution. The first estimate of the price is obtained by applying Eq. (6). In the case where there are no tax losses, this price will stand as the final result. If tax losses are carried forward, the cash flow table will show a capital balance at the end of project life. The product price is adjusted, and the period-by-period computation is repeated until a neg1 igible balance remains at end of $11 \mathrm{fe}$.

In a final summary table in the computer output, the product price is broken down as to source. A cost is calculated for each cost component $m$ as

$$
P_{m}=\frac{\sum_{n} \frac{c_{m, n}}{(1+d)^{n}}}{\sum_{i t} \frac{s_{n}}{(1+d)^{n}}}
$$

Here $C_{m}$ is an individual cost component such as capital investment, income taxes, or materials costs.

In the accounting procedures used in ACFAC, capital investments may be made efther at the beginning or end of the accounting period (year). Income from sales and the expenses are assumed to be paid at the end of the accounting period.

\subsection{Special Considerations}

The following is a discussion of code features and treatment of various items and options. 


\subsubsection{Capital expenditures}

Up to ten separate depreciable capital investments or captal investment groups may be made. Individual capital items may have different construction cash payment schedules, depreciation lifetimes, and investment tax credit treatments. A capital item can be put into operation at any time during the facility life so that replacement of large blocks of equipment may be simulated. The actual lifetime of the facility or equipment might differ from the tax life.

The cost of money used during construction either may be expensed as the expenditure occurs or capitalized. The money used for construction can be from the capital structure (and cost of debt and equity) of the operation or in the form of a construction loan. In the latter case, the interest rate is specified as input.

\subsubsection{Preoperational costs}

These are costs such as manpower training and expenses that occur prior to actual production. The costs are specified for each year prior to operation and will be capitalized or expensed, depending on whether construction money is capitalized or expensed.

\subsubsection{Tax depreciation}

The cost of capital assets cannot be expensed for tax purposes when payment is made but must be depreciated over some period of time. This period need not be the same as the actual life of the item. Depreciation may be taken on the initial cost of the item less its salvage value. In the following discussion, this net value is referred to as $V$. The code contains provision for four methods of computing the depreciation allowance for income tax purposes. These deductions are computed for each capital item and then summed to obtain the total deduction during a period $n$.

- Pro rata depreciation with sales - The total product sales over the plant lifetime is estimated, and depreciation is taken in proportion to the sales in each period.

$$
D_{n}^{T}=\frac{s_{n}}{\sum_{i} s_{n}}(V)
$$


- Straight-1ine depreciation - Depreciation in any year is equal to the reciprocal of the tax life of the asset.

$$
\mathrm{D}_{\mathrm{n}}^{\mathrm{T}}=\frac{\mathrm{V}}{\mathrm{N}_{\mathrm{T}}}
$$

- Sum-of-year's-digits method - The annual depreciation rate is defined as a fraction, the numerator of which is the remaining years of $11 \mathrm{fe}$; the denominator is the "sum of the year's digits." For a nine-year tax 11 fe, the first year's deduction is

$$
D_{1}^{\prime \prime}=\frac{9 V}{1+2+3+\ldots+9}=\frac{9 V}{45} ;
$$

the second year's deduction is

$$
\mathrm{D}_{2}^{\mathrm{T}}=\frac{8 \mathrm{~V}}{45} ;
$$

the ninth year's deduction is

$$
D_{9}^{T}=\frac{V}{45}
$$

- Double-declining balance followed by straight-line depreciation - In the double-declining-balance method, the remalning undepreclated balance is depreciated at a rate double the original straight-line depreciation rate. For the nine-year tax life example,

$$
\mathrm{D}_{1}^{\mathrm{T}}=\frac{2}{9} \mathrm{v}=0.222 \mathrm{~V}
$$

the undepreciated balance is equal to $0.778 \mathrm{~V}$; thus,

$$
\mathrm{D}_{2}^{\mathrm{T}}=(0.222)(0.778) \mathrm{V}=0.1728 \mathrm{~V} \text {, }
$$

elc. 
The Internal Revenue Service allows the change from the decliningbalance method to the straight-line method. When this change is made, the unrecovered cost is spread over the remaining life at the time of change. In our example, the straight-line method produces greater depreciation than the double-declining-balance method in the sixth year.

$$
\begin{aligned}
& \mathrm{D}_{6}^{\mathrm{T}}=0.0633 \mathrm{~V} \text { (double-declining-balance method). } \\
& \mathrm{D}_{6}^{\mathrm{T}}=0.0712 \mathrm{~V} \text { (straight-line method). }
\end{aligned}
$$

The ACFAC program will switch to straight-1ine depreciation in the sixth year in this example.

\section{2 .4 Investment tax credits}

Currently, industry is allowed to deduct a portion of their capital investment cost directly from their federal income taxes. This credit is not applicable to all investments. The computer program allows the user to specify both the fraction of the capital investment on which the credit is applicable and the tax credit rate for each capital item. If the interest during construction and the preoperational costs are expensed, the direct investments are used to compute the tax credit. If these costs are capitalized, the credit is based on the capitalized costs.

For tax liabilities greater than $\$ 25,000$, the 1979 federal tax law 5 allows the investment tax credit to offset up to a maximum of $60 \%$ of tax liability in a given year. Unused credits may be carried forward. The program user can specify this fraction (which may be other than $60 \%$ ); the $\$ 25,000$ minimum is ignored. This maximum tax offset fraction is applied only if the project is a stand-alone venture and not part of a larger corporation with additional tax liabilities.

\section{2 .5 Income taxes}

Both federal and state income taxes are considered. State taxes are deductible for federal tax purposes but not vice versa. Credits for negative state income taxes are not allowed in ACFAC, and there is no tax carry forward for ctate income taxes. The federal law allows for both carry forward and carry back on income taxes and investment credits. 
These unused tax credits and tax losses can be carried forward a maximum number of years specified by the code user. Tax loss carry back is not available in ACFAC.

\subsubsection{Decommissioning expense}

The cost of decommissioning the facility may be provided for in two ways in this code. With the first method, a lump-sum payment at the end of the facility life is specifled. The product price is increased by that amount, which will produce a final capital balance equal to the specified decommissioning cosse.

In the second decommissioning option, a set percentage of sales income is set aside in a trust fund, and the accumulated amount with interest is available for decommissioning at the end of the facility life.

\section{2 .7 Working capital}

In addition to the capital investment in plant and equipment, money needed for the day-to-day operation of the plant must be considered. This capital is referred to as working capital and is not tax deductible because it is assumed to be recovered at the end of plant 11fe. The program user specifies this investment to be paid in at the beginning of the first year of operation and withdrawn at the end of project life.

\subsubsection{Property taxes and insurance}

The code user may specify property tax and insurance rates and the capital base on which they apply. These tax and insurance payments are made during each year of plant operation and are not diminished by deprectation.

\subsubsection{Interim equipment replacement}

In addition to the major equipment purchases (which are treated as capital investments), the year-to-year upkeep and spare parts requirements of production equipment must be included. The program user specifies the capital base for equipment replacement and the fraction replaced in each year. This cost is expensed as incurred. 


\subsubsection{Operating costs}

The program user specifies a full production rate operating cost. This cost is divided into fixed and variable portions. The fixed portion remains the same regardless of the plant operating rate (capacity factor). The variable operating cost is proportional to capacity factor in any given year. In addition to this operating cost, the user may specify up to six sets of year-by-year costs. 


\section{INPUT INSTRUCTIONS}

This section contains a card-by-card description and explanation of the input data required by the ACFAC program.

Card 1. (Format $=20 \mathrm{~A} 4$ ). A title card containing general alphanumeric information.

Card 2. (Format $=20 \mathrm{~A} 4$ ). A second general alphanumer1c 1nformation card.

Card 3. (Format $=20 \mathrm{~A} 4$ ). A third general alphanumeric information card.

Card 4. (Format $=1315$ ). Control information.

NLIFE: Number of years plant is to be in operation.

NCAP: Number of capital cost items to be read in as input. Maximum number $=10$.

NDTYP: Tax depreciation option to be used.

0 = capital investment written off pro rata with unit sales;

1 = straight-1ine depreciation;

2 = sum-of-year's-digits depreciation;

3 = double-declining-balance depreciation method followed by straight-line depreciation when it produces the maximum allowable deprectatinn.

IDCC: $0=$ Money used during construction obtained from same sources as during operation. Preoperational costs and interest paid on debt are expensed as they occur.

1 = Capitalize all construction costs including interest and preoperation costs. Cost of construction loan given as input (see AINC on card 6).

2 = Same as. 1 , only interest rate on conseruction money is equal to the average cost of money during operation.

-1 - Money used during construction obtained from construction loan. Interest rate $=$ AINC (see card 6). Expense interest and preoperation costs as they occur.

-2 = Same as -1 except interest and preoperation costs are accumulated and expensed at start-up for tax purposes.

INIT: Preoperation period included in cash flow analysis (years). This number must be equal to or greater than the inftial construction and design period. 
IEND: Postoperation period included in cash analysis (years).

ITC: $0=$ investment tax credit not included.

$1=$ investment tax credits are to be included in the cash flow analysis.

NTAX: $0=$ Tax losses cannot be written off agalnst other undefined earnings.

1 = Negative federal income tax allowed; tax losses can be written off against other earnings. (If NTAX $=0$, tax losses are carried forward to a maximum of NCRY or NITCF years.)

NDEC: Decommissioning expense option.

$0=$ Decommissioning not considered.

1 = A 1 ump-sum payment at end of plant $11 \mathrm{fe}$ is specifled.

2 = Decommissioning money is accumulated in a trust fund. Payments into fund, as a percentage of sales and interest rate on the funds, are to be specified on card 7.

NCRY: Number of years a tax 1 oss may be carried forward.

NITCF: Number of years an investment tax credit can be carried forward if $1 \mathrm{t}$ is not used when available.

IOUT: $0=$ Cash flow printout for final iteration only. 1 = Cash flow printout for every iteration.

NPAY: 0 = Capital investment payments at beginning of year. 1 = Capital investment payments at end of year.

Card 5. (Format $-8 \mathrm{E} 10.3$ ). Economic factors.

EINT: Return on equity investment (fraction per year).

BINT: Interest rate on borrowed money (fraction per year).

BFRAC: Fraction of capitalization from debt.

FTRAT: Federal income tax rate (fraction per year).

STRAT: State income tax rate (fraction per year).

TREF: Year's dollars in which costs are specified.

FITR: Maximum fraction of income tax liability which investment tax credit can offset in a given year.

CONV: Convergence criteria, convergence tolerance for cash flow analysis (millions of dollars). 
Card 6. (Format 7E10.3).

WORK: Working capital $\left(\$ 10^{6}\right)$. This quantity of money is paid in at the beginning of the first year of operation and withdrawn at the end of the operation $11 \mathrm{fe}$.

AINC: Interest rate during construction (fraction). This rate is used during construction period if IDCC on card $4=1,-1$, or -2 .

CPRT: Property tax rate (fraction per year).

CINS: Property insurance rate (fraction per year).

YRCST: Interim equipment replacement rate (fraction per year). CRPL: Original equipment cost to which YRCST applies $\left(\$ 10^{6}\right)$.

CAPV: Capital base for insurance and property tax purposes $\left(\$ 10^{6}\right)$.

Card 7. (Format 7E10.3).

PWU: Full production rate (units per year).

TO: Year production is to begin.

CSTM: Annual cost of materials at full production ( $\$ 10^{6} /$ year).

CSTO: Annual operating cost (excluding materials) at full production $\left(\$ 10^{6} /\right.$ year $)$.

AOPER: Fraction of operating cost that is independent of production rate.

BOPER: Fraction of operating cost that is proportional to annual production.

DECOM: If NDEC $=1$ (card 4), 1 ump-sum decommissioning cost at end of plant 1 ife $\left(\$ 10^{6}\right)$.

If $\mathrm{NDEC}=2$ (card 4 ), payment rate into decommissioning annuity (fraction of total sales income).

ANINT: Interest rate pald on decommissioning annulty (fraction per year).

Card 8. (Format 8E10.3). There are NLIFE +1 of these cards, which contain information on the plant capacicy factor and additfonal cash payments not covered by the balance of the input. Each card contalns the following:

RELT: Time relative to beginning of plant operation. Begin numbering at 0.0 and end at NLIFE on NLIFE +1 card.

PWF: Plant capacity factor during preceding period ending at RELT. 
OTHCST: Maximum of six of these items. Cost expended at time RELT $\left(\$ 10^{6}\right)$. Cards 9 and 10 are taken as a set. There is one set of these cards for each of NCAP (see card 4) capital cost items. A maximum of ten capital cost items is allowed.

Card 9. (Format 4I5, 4E10.2).

NONL: Year (relative to plant start-up) that capital cost item is put on line.

LDEP: Depreciation lifetime (years).

NYSL: Actual life of capital item (years).

NBLD: Construction period, years prior to year item is put in service.

VCAP: Capital cost, excluding interest during construction $\left(\$ 10^{6}\right)$.

VSAL: Salvage value at end of life $\left(\$ 10^{6}\right)$.

FITC: Fraction of capital cost applicable for investment tax credit $\left(\$ 10^{6}\right)$.

RITC: Investment tax credit rate (fraction).

Card 10. (Format 8E10.3). Cash payment schedule for capital items

during construction (BLDS). There are NBLD (see card 9) entries on this card (or series of cards). The first field contains the fraction of the total capital cost (VCAP) paid during the first year of construction. Subsequent fields contain cost fraction for subsequent years. The total of a1l fields $=1.0$.

Repeat cards 9 and 10 for each of NCAP capital cost items.

Card 11. (Format 8E10.3). Preoperational cost payment schedule (PROP) $\left(\$ 10^{6} /\right.$ period). There are INIT (see card 4) entries on this card (or series of cards). Payments in each period are entered in subsequent fields beginning with the first year of the preoperational period and ending with the year before start-up. If the preoperational costs are capitalized, the computer code will include and depreciate these costs with the first capital item from card 10.

Card 12. (Format I5). Option to stack cases.

NCLUE: $0=$ Last case in series.

1 = Another case follows. 


\section{EXAMPLE PROBLEM}

The example problem is to estimate the cost of manufacturing lowenriched uranium fuel for a pressurized-water reactor. The ground rules used for this problem are similar to but not exactly the same as those used to calculate product price in Ref. 1. The hypothetical fuel fabrication plant has an annual throughput of $520,000 \mathrm{~kg} /$ year of fuel heavy metal content at full operating capacity.

The input data for the problem are shown in Fig. 1. The operation is assumed to be a stand-al one venture; therefore, negative income taxes are not allowed. The corporate capitalization is $65 \%$ equity and $35 \%$ debt. The cost of bonded debt is $8.3 \%$, and the needed return on equity capital is $14 \%$.

of the operating costs, $10 \%$ are fixed and $90 \%$ are variable; $1 \%$ of sales income is set aside each year for decommissioning the plant and is accumulated at $8 \%$ interest.

There are different cash payment schedules for the bulldings (facility) and for the inftial equipment. These cash payments are assumed to be made at the beginning of the year. The equipment is assumed to be replaced en masse during the eleventh year of operation. This is in addition to a $1 \%$ interim replacement rate. The plant capacity is $33 \%$ the first year, $67 \%$ the second year, and full (100\%) capac1ty thereafter. The interest during construction and preoperational costs were capitalized; construction money interest is $10.5 \%$.

An investment tax credit rate of $10 \%$ is used. Half of the facility and all of the equipment are applicable for the credit in this example problem. The output from the example problem is given in Appendix $C$. Input data are 11sted in the first four pages of output, along with explanatory notes. A list of period-by-period expenses is given on the fifth page of output. The capacity factor is that applicable during the operating year given. Expenses are those charged at the time point. For example, there is a 0.33 capacity factor during the first year of operation, and the material cost of $\$ 7.6 \mathrm{mill}$ ion is expensed as if it occurred at the end of year one ( $t$ ime point $=1.0$ ). Al so given on this page are discount rates and total production and total discounted production. 


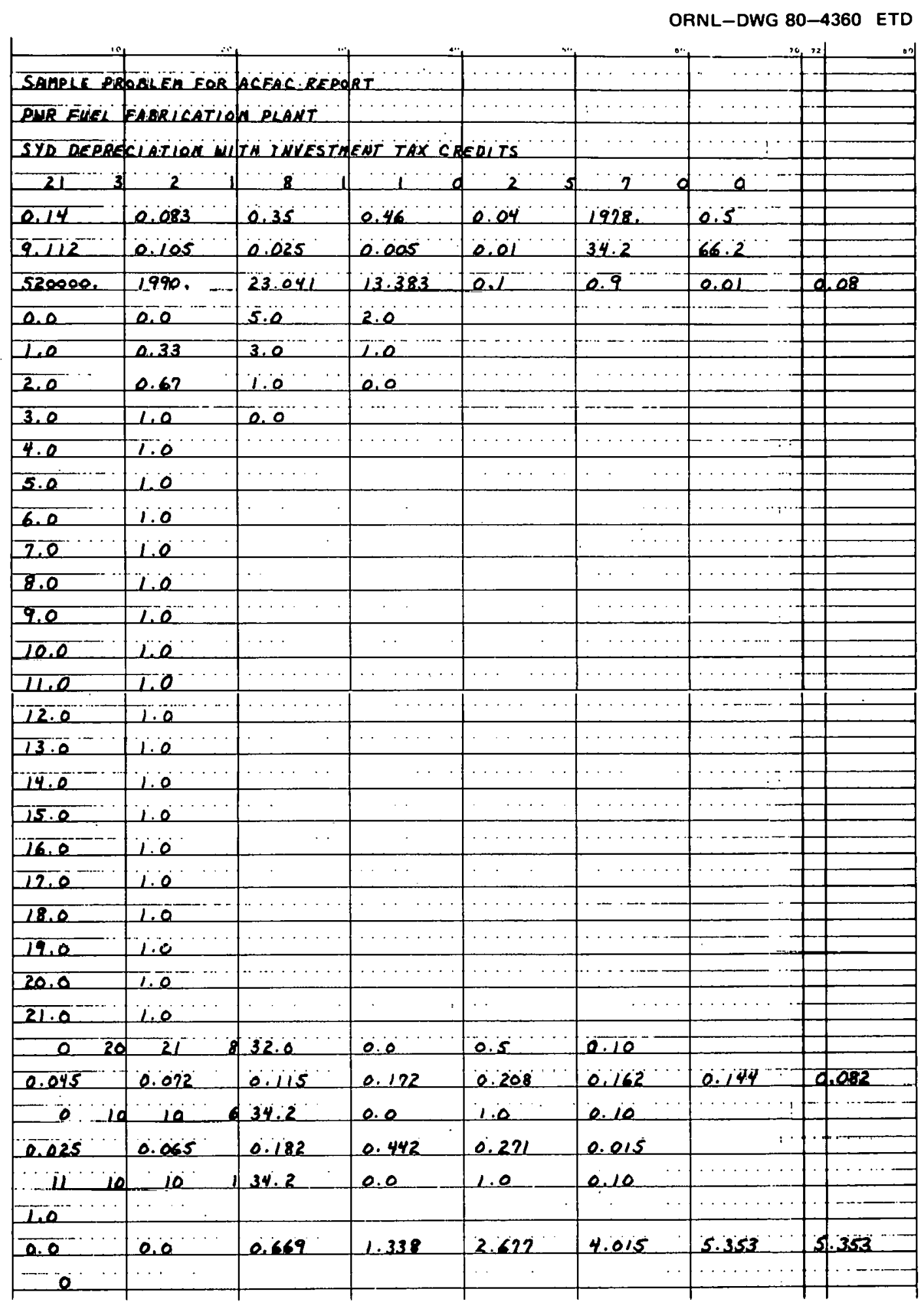

Fig. 1. Sample problem input data. 
The sixth page of output contains the cash flows for capital investment and the tax deductions for depreciation purposes. Time here is the actual year (assuming 1990 start-up) as given in the input data (TO on card 7). The year given is again the time point for cash flow. In the example problem, capital investments are assumed to be paid in at the beginning of the time period (NPAY on card 4); thus, the $\$ 1.44$ million capital investment made during 1982 is treated as a cash flow occurring at 1982.0. If the option to pay for capital investments at the end of the period had been selected, the $\$ 1.44 \mathrm{million}$ would have been treated as a cảsh flow occurring at 1983.0 and would have shown up nn, the 1983 line in this table.

Taxes are assumed to be paid at the end of the period in which the taxable income is generated. The tax depreciation is an expense for tax calculation purposes and is used to reduce taxes, which, in turn, are treated as a cash flow at the end of the period. For example in the sample problem, the deduction for depreclation during the first year of operation (beginning 1990) is $\$ 15.58$ million and is applied at the end of the year so that $i t$ shows up as a credit at time 1991.0.

The next page of output is a summary table of cash fluw fruin the final code iteration. Time does not represent time points in this table but the year in which the transactions occur. Therefore, the direct capital investment should be thought of as occurring at the start of the year; and income, expenses, taxes, and return on and of capital should be thought of as occurring at the end of the year in question. Because negative taxes were not allowed in the example problem, multiple iterations occurred to arrive at the cash flow on this summary table. If a cash flow printout is desired for each iteration, set IOUT $=1$ on input card 4 .

This cash flow summary table shows that the income from sales at a product price of $\$ 130.71 / \mathrm{kg}$ pays the required return each year on startof-year (outstanding) capital and reduces the outstanding capital to zero at the end of project $11 \mathrm{fe}$.

A breakdown of the product price by cost component is contained on the final page of output. This cost breakdown was obtained by applying Eq. (8) (discussed earlier in this report). In the example, the preoperation cost component is set equal to zero because this cost is capitalized 
and included with capital recovery. If the money used during construction were not capitalized (IDCC negative on card 4), the interest pald during construction would have been included under preoperation costs in this breakdown.

The final value of the fund to decommission the plant is also shown on this page. The value of $\$ 31.2$ million is about one-hal $f$ of the initial facility plus equipment cost. 


\section{REFERENCES}

1. R. R. Judkins and A. R. Olsen, Estimation of Costs for Fabrication of Pressurized-Water Reactor Fuel, ORNL/TM-6501 (January 1979).

2. Royes Salmon, PRP - A Discounted Cash Flow Program for Calculating the Production Cost (Product Price) of the Product from a Process Plant, ORNL-5251 (March 1977).

3. M. W. Rosenthal et al., A Comparative Evaluation of Advanced Converters, ORNL-3686. (January 1965), pp. 243-48.

4. Guide for Economic Evaluation of Nuclear Rearetor Pl.ant. Designs, Nus531 (January 1989), Appendix k..

5. Department of the Treasury, Internal Revenue Service, Tax Guide for Small Business, 1979 Edition, Publication 334 (revised November 1978), p. 143. 
Appendix A

NOMENCLATURE

$\mathrm{C}_{\mathrm{m}, \mathrm{n}} \quad$ Cash flow associated with cost component $\mathrm{m}$ during time period $\mathrm{n}$

$D_{n}^{T}$ Tax-deductible depreciation during period $n$

d Discount rate based on weighted-average cost of money

$\mathrm{F}_{\mathrm{b}} \quad$ Fraction of capitalization from debt

$\mathrm{F}_{\mathrm{e}} \quad$ Fraction of capitalization from equity

$\mathrm{I}_{\mathrm{n}} \quad$ Income during period $\mathrm{n}$

$i_{b} \quad$ Interest rate on debt

$i_{e} \quad$ Return on equity

m Index associated with a cost item

$\mathrm{N}_{\mathrm{T}} \quad$ Tax 1ifetime

$\mathrm{n} \quad$ Index associated with time period

$\mathrm{O}_{\mathrm{n}} \quad$ Total operating costs during period $\mathrm{n}$

$\mathrm{O}_{\mathrm{n}}^{-} \quad$ Total operating costs (excluding income taxes) during period $\mathrm{n}$

P Levelized average price of product

$P_{m} \quad$ Levelized average price produced by cost component $m$

$P_{n} \quad$ Price charged for product during period $n$

$r$ Effective income tax rate

$\mathrm{S}_{\mathrm{n}} \quad$ Sales of product during period $\mathrm{n}$.

V Net depreciable cost (cost - salvage)

X Tax-adjusted discount rate

$\mathrm{z}_{\mathrm{n}} \quad$ Investment in depreciable capital in period $\mathrm{n}$ 
THIS PAGE

WAS INTENTIONALLY

LEFT BLANK 
Appendix B

FORTRAN LISTING 


\section{THIS PAGE \\ WAS INTENTIONALLY \\ LEFT BLANK}




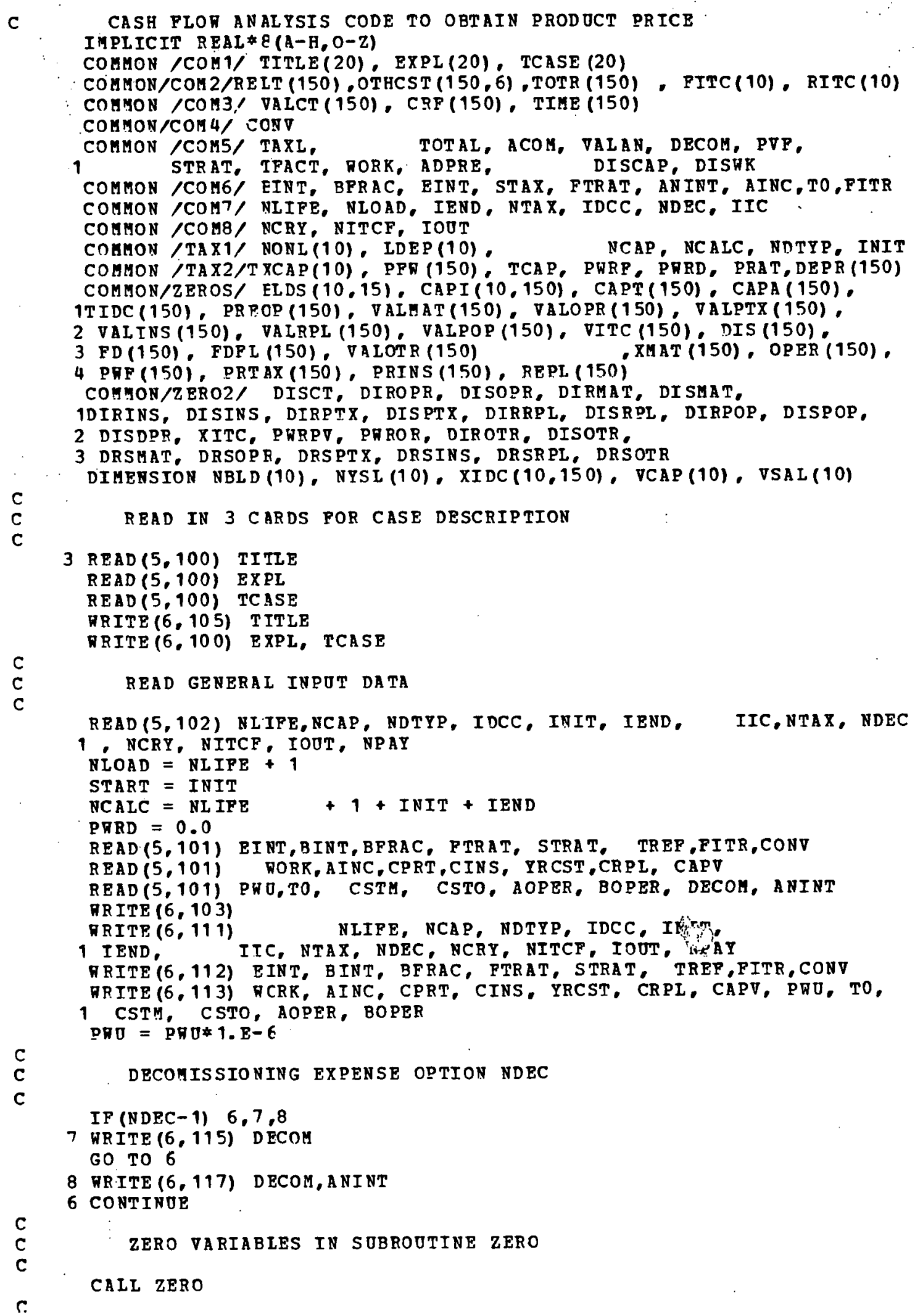




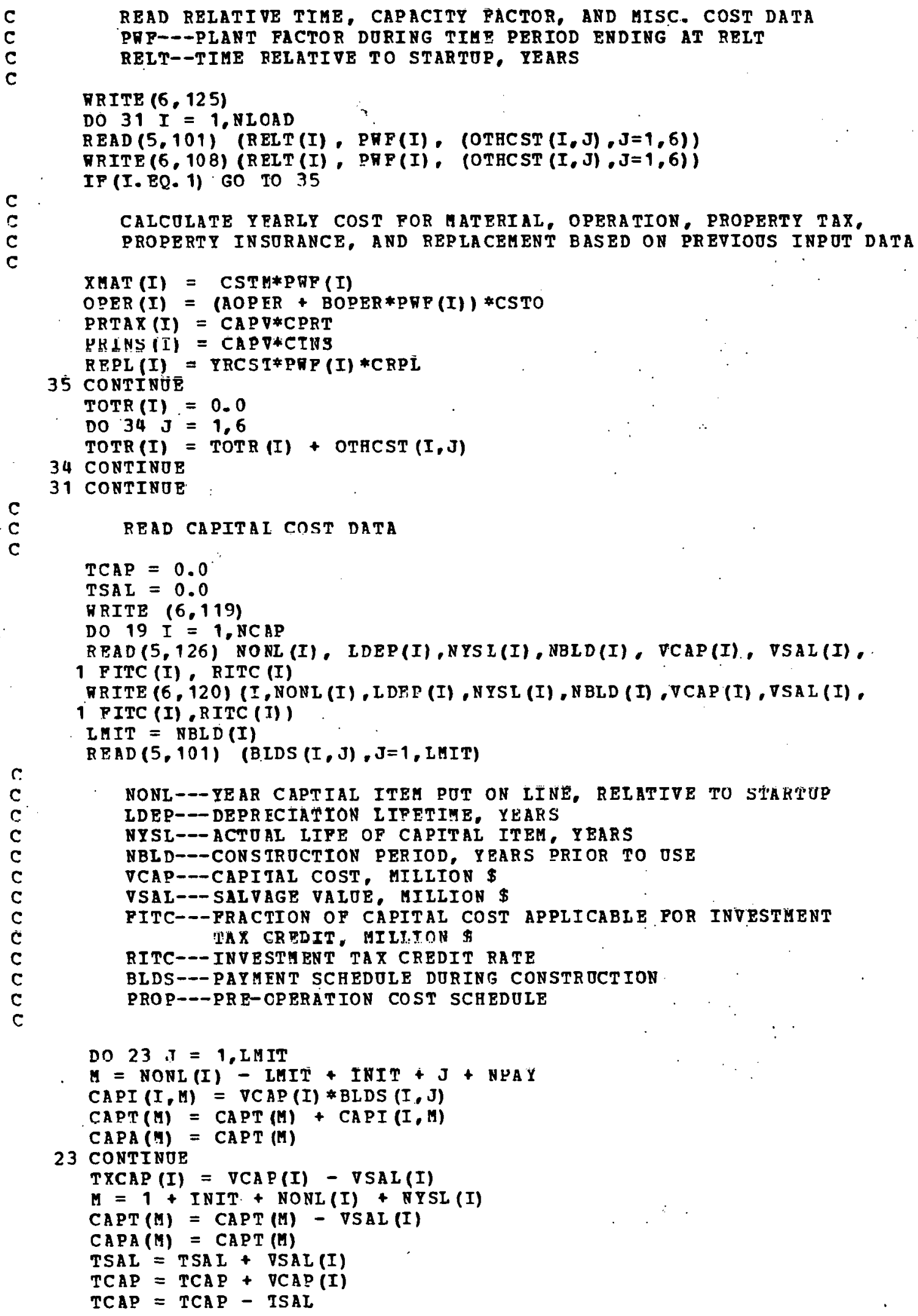




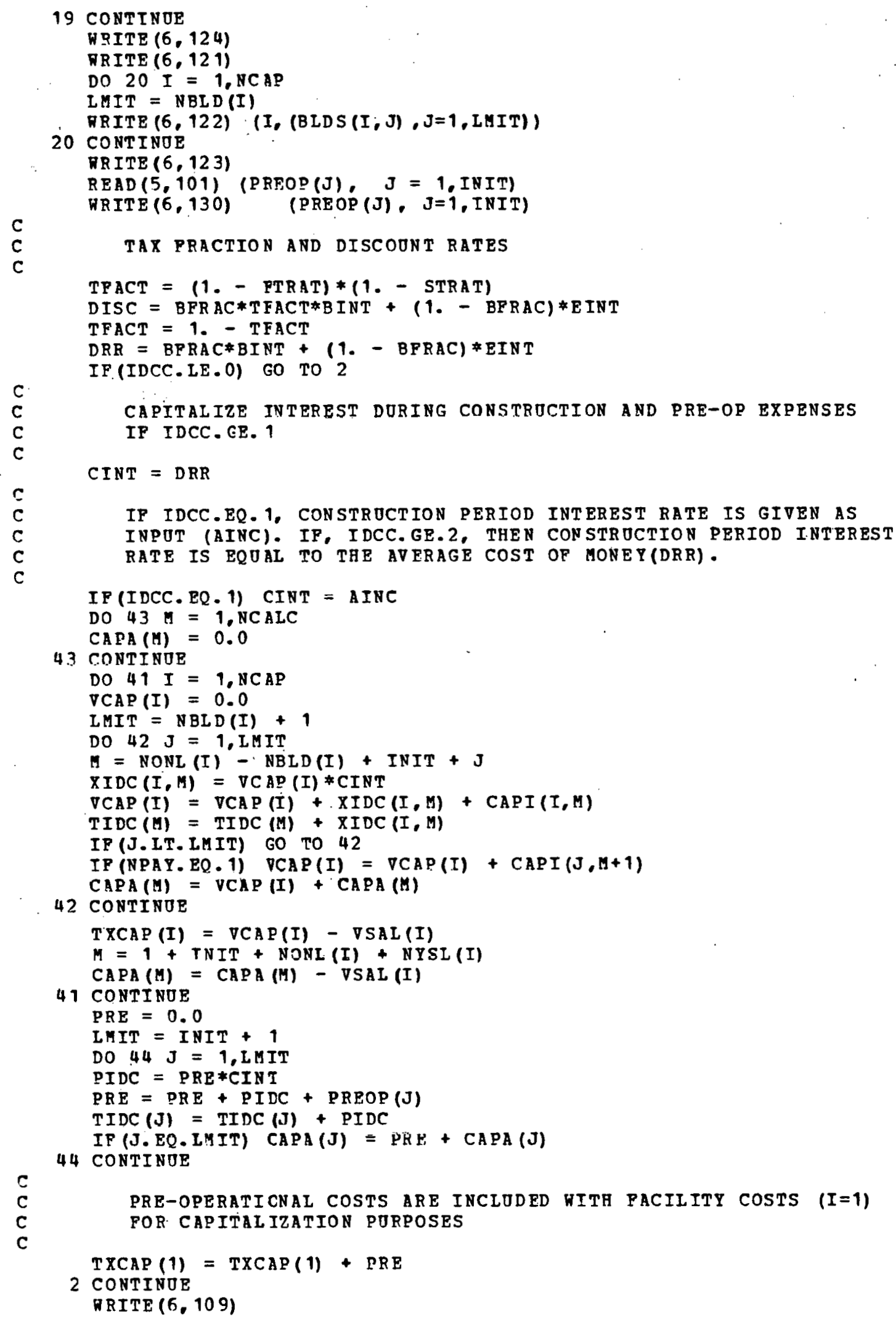




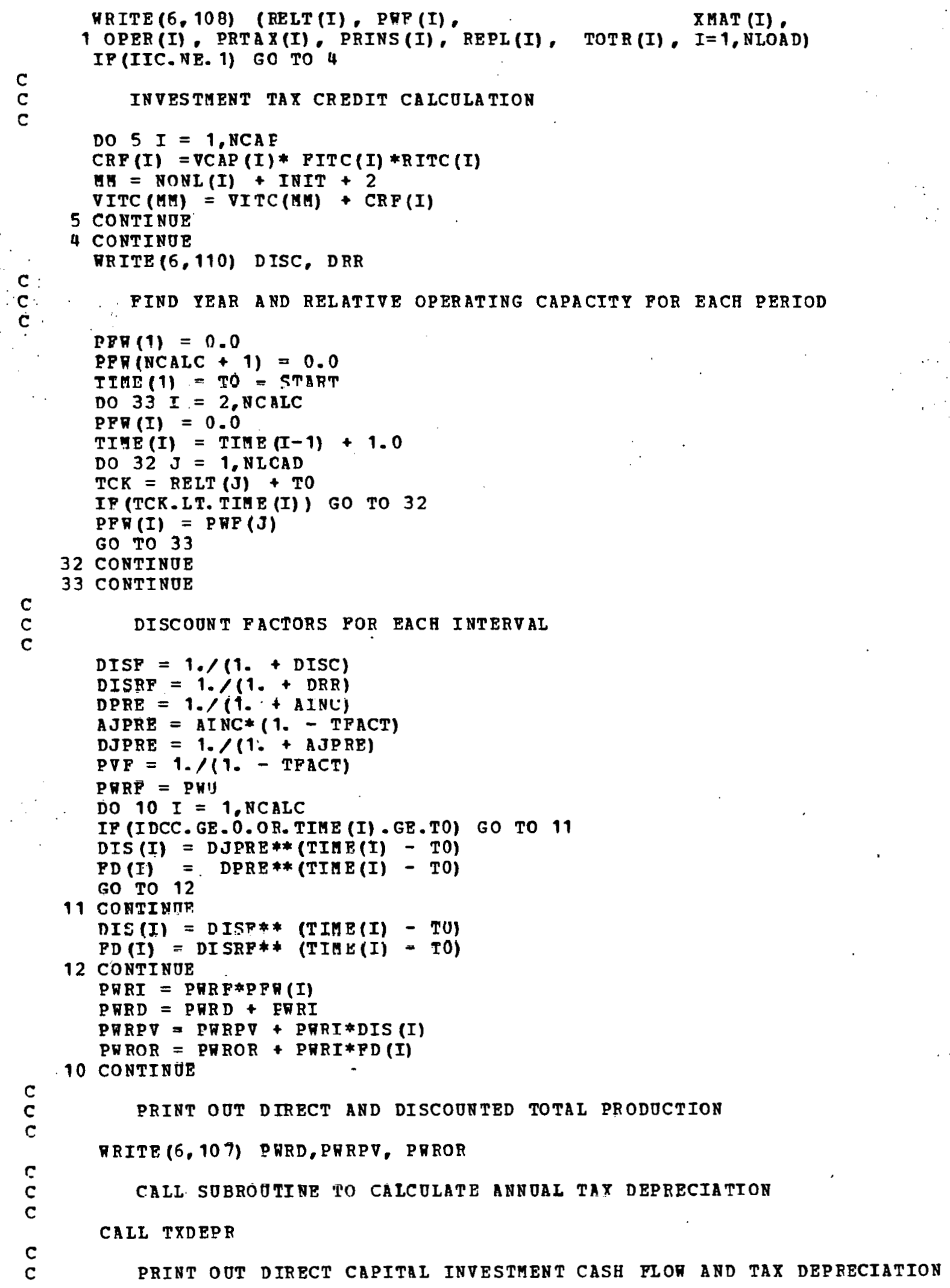


C

C
C
C
C
C
C
C
C
C
C
C

VRITE $(6,127)$

DO $28 I=1$, NCALC

DRITE $(6,128)(\operatorname{IIME}(I) ;(\operatorname{CAPI}(J, I), J=1,8), \operatorname{CAPT}(I), \operatorname{DEPR}(I))$

28 CONTINOB

SUBROOTINE 'SOLVE' CALCOLATES UNIT PRODOCT PRICE USING

THE THEORET ICAL SOLUTION

CALL SOL VE:"

SOBROUTINE 'CASH' LAYS OUT THE YEAR BY YEAR CASH FION AND

RECALCOLATES PRODUCT PRICE IF AN ITERATIVE SOLOTION IS REQOIRED

CALL CASH

PRINT OOT ITEHIZED ONIT COST

NRITE $(6,105)$ TITLE

RRITE $(6,100)$ TCASE

VRITE $(6,100)$ EXPL

WRITE $(6,104)$ D ISCAP, DRSHAT, DRSOPR,DRS PTX,DRSINS, DRSRPI, DRSOTR,

1 ADPRE, DISRK, TAXL

IF (NDEC.NE.0) RRITE $(6,116)$ ACOM

ARITE $(6,114)$ TOTAL

IP (NDEC. EQ.2) VRITE $(6,118)$ VALAN

$c$
c

READ $(5,102)$ NCIOE

STACR CASES IF NCLUE.GE. 1

TF(NCLUE.GE. 1) GO TO 3

DRITE $(6,129)$

100 PORMAT (20A4)

101 PORMAT (8E10.3)

102 FORHAT (16I5)

103 PORMAT (180, CARD 4, GENERAL INPUT INFORMATION, $(0=$ NO, $1=$ YES) $1 . / / .1$

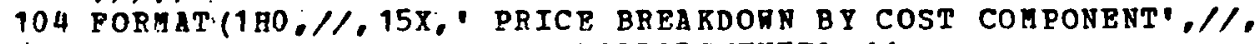

A 11X, LEVELIZED COSTS, DOLIARS/UNIT.//,

11. CAPIT AL RECOVERY : F8.2.1\% MATERTAL

2. OPERATING $\because$ FB. $\%$ \%, PROPERTY TAX

3! PROPERTY INSORANCE, F8.2. $/ \%$ REPLACEMENT

4. OTHER OPERATING $\because$ F8.2. $\%$ PRE-OPERATION

5. DORKING CAPITAL ',P8.2. $/, 1$ IXCOME TAX

$$
\begin{aligned}
& \text {. P8. } 2.11 . \\
& \because \mathrm{P} 8.2 .11 . \\
& \because \text { PB. } 2.1 / \\
& \text {-F 8.2.11. } \\
& \text { ๑. } 8.2)
\end{aligned}
$$

105 PORMAT (1B1, 20A4)

107 PORMAT (1HO, 'LIFETIME PRODOCTION, MIILIONS OF ONITS', 15X,P12.4,//. 1. DISCOONTED L IFETIME PRODUCTION $, 1 /, 10 \mathrm{X}, 1 \mathrm{AT}$ TAX ADJOSTED DISCOUN 2 RATE $, 14 X, F 12.4,1 /, 10 X, \cdot A T$ DISCOUNTED CASH FLOH RATE OF RETURN',5 $3 X, F 12.4)$

108 FORHAT (F7.2, 7 P 12.2)

109 FORMAT (1H1, SCHEDOLE OF EXPENSES, MILLIONS OF DOLLARS, //, 1 TEAR CAPACITY MATERIAL OPERATION PRÓ. TAX PROP. 2INS REPLACEMENT OTHER EXPENSES')

110 PORMAT (1H0,'TAX ADJOSTED DISCOONT RATE, $31 X$, F8.5.1/.' DISCOUNTED 1 CASH FLOF RATE OF RETURN' $23 X, F 8.51$

111 PORMAT (' NOHBER OP OPERATION YEARS',31X, I5./1,

1. NUABER OP CAPITAL ITEMS TO BE READ

2. TAX DEPRECIATION OPTION

3. INTEREST DURING CONSTRUCTION OPTION

4. PRE-OPERATION PERIOD INCLODED IN CASH ANALYSIS, YEARS

5. POST-OPERATION PERIOD INCLODED IN CASH ANALYSIS, YEARS

6. IS INVESTMENT TAX CREDIT TO BE CONSIDERED?

7. CAN TAX LOSSES BE VRITTEN OPF AGAINST OTHER EARNINGS?

8. DECOMMISTON EXPENSE OPTION TO BE USED

9. NOMBER OF YEARS TAX LOSS MAY BE CARRIED FORWARD 
A NOMBER OP YEARS INVESTMENT CREDTT MAY BE CARRIED FORAARD', I5.//,

B. CASH PLON PRINTOUT. FOR BACH ITERATION

C. CAPITAL INVESTMENT PAYMENT OPTION

112 FORMAT (1H1, I IP OT INPORMATION ON CARD 5

1. RETURN ON EQUITY INVESTHENT, FRACTION

2. INTEREST RATE ON CAPITALIZED DEBT, PRACTION

3. FRACTION OP CAPITALIZATION FROM DEBT

4. PEDERAL INCOHE TAX RATE. FRACTION

5. STATE INCOME TAX RATE, FRACTION

6. COSTS ARE IN DOLLARS OF THIS YEAR

AXIMOA PRACTION OP TAXES NHICH TAX CREDIT CAN OPPSET . P10.3./\%,

8. CASH PLON CONVERGENCE TOLERANCE, HILLION \$ Y P10.3)

113 PORMAT (1HO, INPOT INFORMATION ON CARDS 6 AND $7 \% / /$.

1 MORKING CAPITAL, MILLION $\$$

2. INTEREST DUR ING CONSTRUCTION

3. PROPERTY TAX RATE

4. INSORANCE RATE

5. INTPRI REPLACEMENT RATE

6. CABITAI VATIIR FOR TNTERTI REPL, PORPOSES, MIILION \$

7. CAPITAL BASE POR INS. AND PROP. TAX, MILLION \$

8. POLL PRODUCTION RATE, UNITS/YBAR

9. YEAR PRODUCTION IS TO BEGIN

A. MATERIAL COST AT PULL PRODUCTION, MILLION \$/YEAR

B. OPERATION COST AT PULL PRODOCTIOR, MILLION \$/YEAR

C. FIXED COST PRACTION OF OPERATION COST

D OPERATING COST FRACTION PROPORTIONAL TO PRODDCTION

$. \mathrm{F} 10.3 .1 /$

$\because \mathrm{P} 10.3 .1 \%$

$\because \mathrm{P} 10.3 .1 \%$

$\because \mathrm{P} 10.3 .1 \%$

$\because \mathrm{P} 10.3 .1 \%$

4 PORMAT (2OX,-

115 FORMAT (" LUMP SUM DECOMMISSIONING COST, MILION $\$ 1,14 X, F 10.3$ )

116 FORMAT (1H0, DECOMISSIONING, $\mathrm{F} 8.2)$

117 FORHAT(" DECOMUISSIONING EXPENSE AS PRACTION OF SALBS1 10X,F9.3.//. 1 INTEREST PAIC ON DECOHMISSIORTNG EXPENSE ANNOITY

118 FORHAT (1HO, PINAL VALOE OF ANNOTTY TO DECOMHISSION PLANT = " 1 P9.3.' MILIICN DOLLARS')

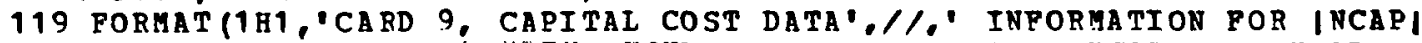
1CAPITAL ITEMS', $/ /$ ITEM NONL IDEP NYSL NBLE VCAP VSAL 2 PITC RITC', /

120 PORMAT (5I5, 4P 10.3)

121 PORMAT (1HO, CARD 10, CAPITAL PAYMENT SCHEDULE DORING CONGTROCTION 1. FRACTION OP TOTAL ', IN, ITEH CONSTROCTION PAYHENT TN RACH YE 2AR OF CONSTROCTION PERIODINBLDI',/)

122. FORMAT (I 4, 12F9.3)

123 PORMAT (1HO, ICARD 11, PRE-OPRRATION EXPENSE SCHEDULE',//, 1. MILIIONS OP LOLLARS PATED IN EACH OF |INIT| YEARS PRIOR TO OPERA 2TION')

124 FORMAT (1H0, 6X, 'NONL---YRAR, RELATIVE TO STARTOP, THAT CAPITAL ITEM

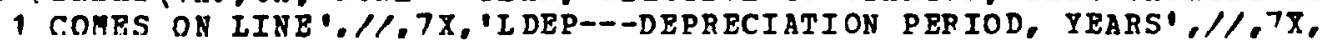
2'NYSL-- LIFE OP CAPITAL ITEK, YEARS $, 1 /, 7 \mathrm{X}, 1$ NBID---CONSTROCTION PE 3RIOD, YEARS', $/ 1,7 X, 1$ VCAP-COST OF CAPITAL ITEH, MILIION $\$ 1.1 / .7 X$, 4.VSAL--SALVAGE VALUE AT END OP IIFE, MILLION $\$ 1 / .7 X, \cdot F T T C--C A Y$ 5TTAL COST APPLICABLE FOR INVESTMENT TAX CREDIT, MILIION $\$ 1 . / 1.7 \mathrm{X}$, 6'RITC-- INVESTMENT TAX CREDIT RATE, FRACTION')

125 FORMAT (1H1, 'CARD 8, CAPACITY FACTORS AND HISCELLANEOUS EXPENSES $1,1 /$. YEAR CAPACITY',26X, OTEER COS'ITEAS')

126 FORHAT (4I5, 4810.2)

127 PORMAT (1H1, C APITAL INVESTMENT CASH FLON, MILION $\$ 1, / /, 1$ TIM 18'.28X. MAXIMUM OP EIGHT CAPITAL ITEMS ,28X,' TOTAL TAX DEPR')

128 FOREAT (11P 10.2)

129 FORIAT (1H1 'BND OP JOB')

130 PORMAT (12F 9.3)

STOP

END 


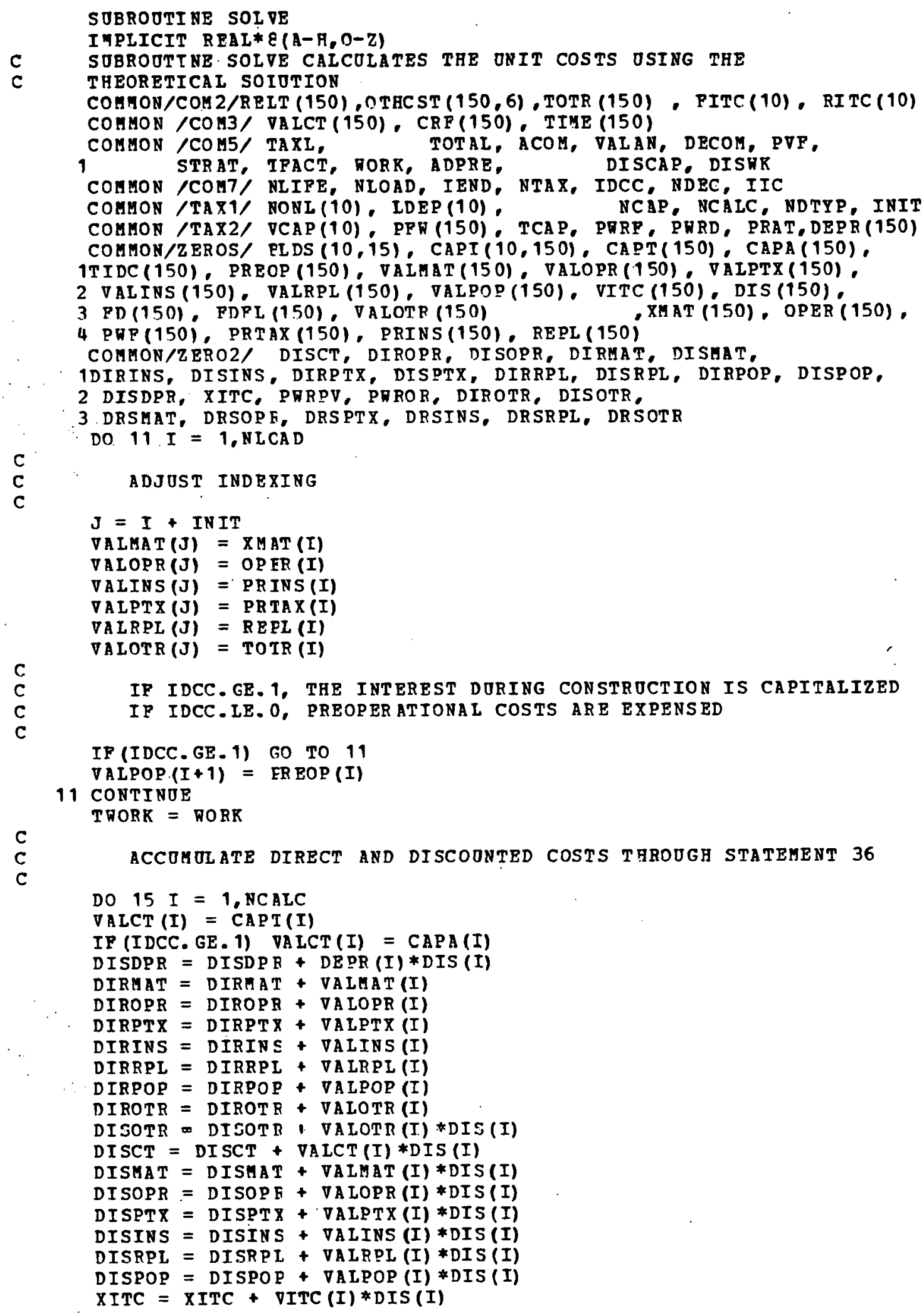




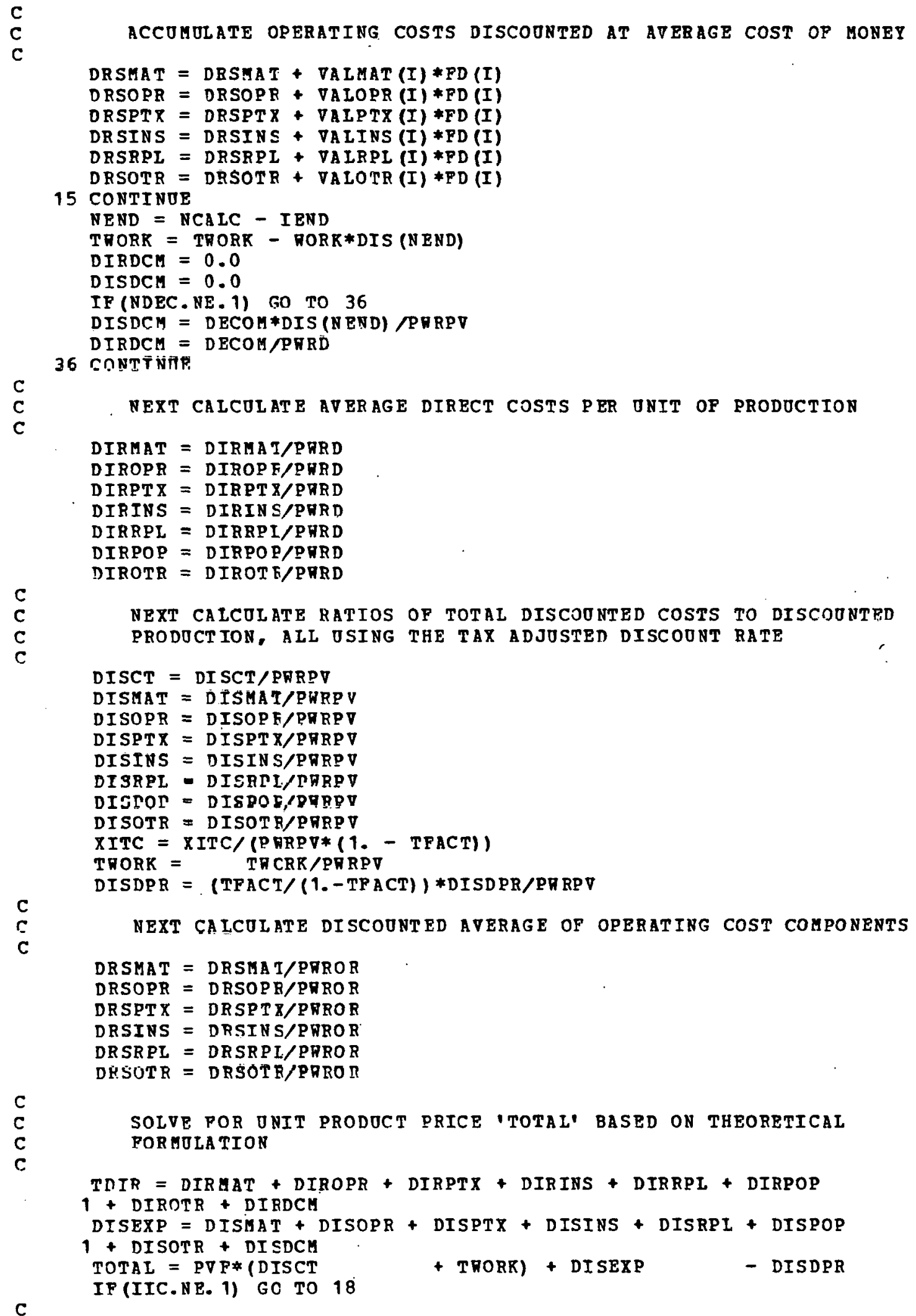




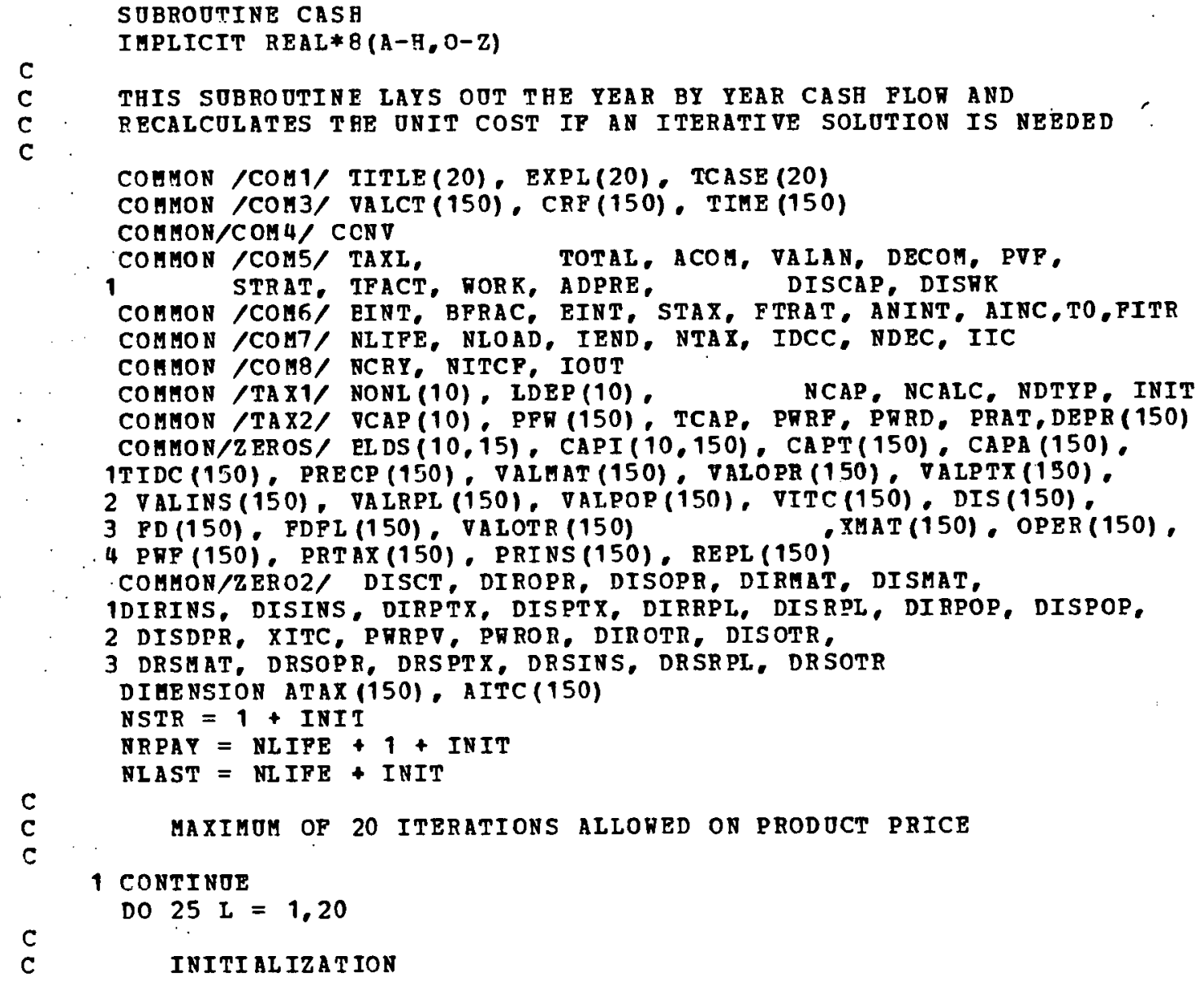




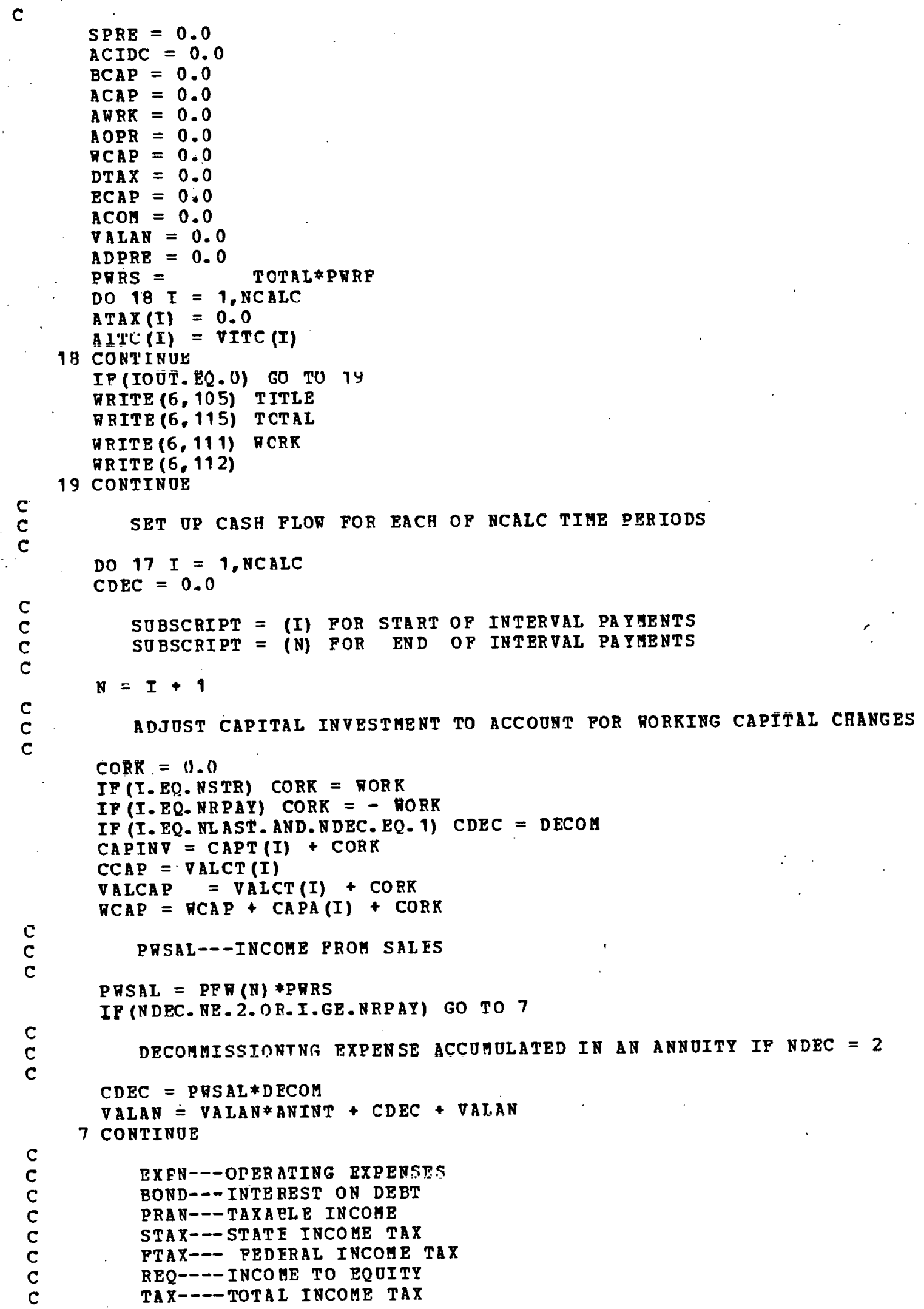


C

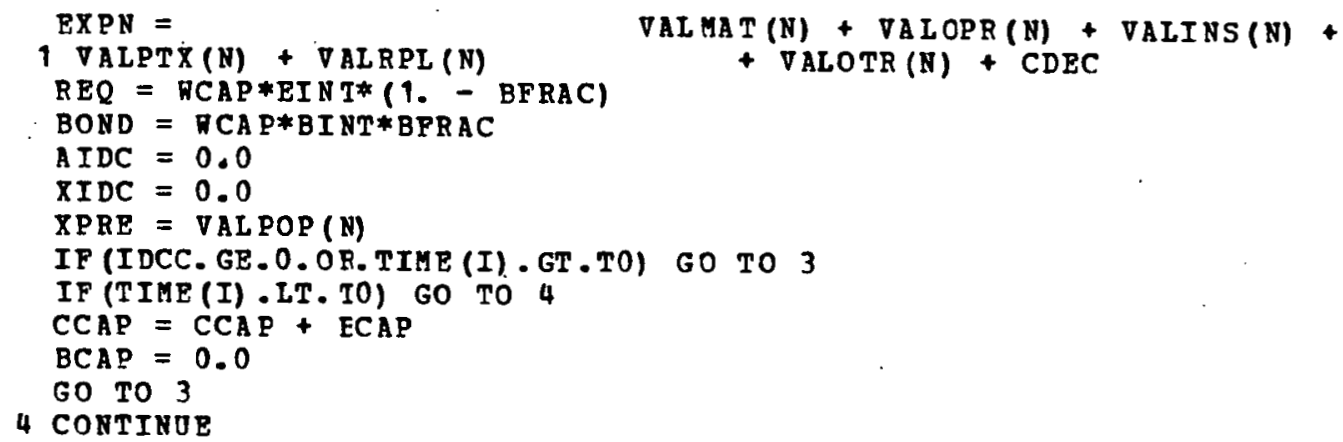

POR OPTIONS IDCC.LT.0, THE IDC RATE IS GIVEN AS INPOT. THE INTEREST DORING CONSTROCTION IS BROKENOUT SEPARATELY IN THE OOTPOT AND IS THE RETUR ON INVESTED CAPITAL IN THIS CASE. THE ACCUMULATED INTEREST DURING CONSTRUCTION + CAPITAL INVESTIENT IS THE FOTURE VALUE OF THE DIRECT CAPITAL INVESTMENT, THEREPORE THE DISCOONT RATE DORING CONSTRUCTION (FD) IS SET $=1.0$.

$P D(N)=1.0$

$\mathrm{REQ}=0.0$

$B O N D=0.0$

AIDC $=$ RCAP*AINC

$\operatorname{TIDC}(\mathrm{N})=A I D C$

$B C A P=B C A P+C C A P$

CCAP $=0.0$

IF (InCC. LE. - 2) GO TO 5

$c$
$c$

IF IDCC IS EQDAL TO -1, EXPENSE PRE-OPERATION COST AS INCORRED

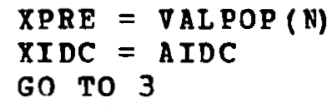


TAX = PTAX

IF (TAX.GE.0.0) GO TO 20

$\operatorname{ATAX}(N)=-T A X$

$\mathrm{TAX}=0.0$

GO TO 26

20 CONTINOE

DO $21 K=1, N C B Y$

$M=N-N C R Y+K-1$

IF (H.LP. O) GO TO 21

BTAX = DMIN1 (ATAX(M), TAX)

TAX = TAX - BTAX

$\operatorname{ATAX}(M)=\operatorname{ATAX}(\mathrm{I})-\operatorname{BTAX}$

IF (TAX:LE,0.0) GO TO 26

21 CONTINOE

TF(IIC.EY.O) GO TO 26

$N L V=N I T C F+1$

DO $22 K=1$, NL

$M=N-N I T C P+R-1$

IF (H.LE. O) GO TO 22

$\mathrm{XTX}=$ PITR*TAX

BTAX = DMIN $1(\operatorname{ITC}(\mathrm{I}), X T X)$

TAX = TAX - BTAX

$\operatorname{ATC}(M)=\operatorname{ATTC}(M)-B T A X$

IF (TAX.LE. 0.0) GO TO 26

22 CONTINOF

26 CONTINOE

C

STATE INCOME TAX IOSS NOT CARRIED PORNARD

$T A X=S T A X+T A X$

27 CONTINOE

CFLOR,PFLOW--- CASH FLON DURING PERIOD

RCAP, PCAP-- MONEY LEFT OVER, OSED TO REDUCE OOTSTANDING CAPITAL

COUT, RCAP---OOTSTANDING CAPITAL

TIDC---INTEREST DURING CONSTRUCTION

PREOP-- CAP ITALIZED PRE-OPERATIUN COSTS

VALPOP-D-EXEENSED PRE=OPERATION COSTS

BCAP---END OF PERIOD OUTSTANDING CAPITAL

CPLOV = PHSAL - EXPN - TAX - VALCAP - VALPOP(N) - ATDC

RCAP = CPLON - BOND - REQ

COUT = HCAP

PPLOH = CPLOW

PCAP = RCAP

C

IP (IDCC.LE.0) GO TO 14

IF IDCC.GE. 1, IDC AND PRE-OP COSTS ARE CADITALIZED AND

WILI BE INCIUUEU WITH CAPTTAL RECOVERY IN ITRMTZATTON.

COUT = CAPINV + BCAP

CONST $=$ CAPINV + TIDC $(N)+$ PREOP (I)

PFLON = CFLOR - CONST + VALCAP

PCAP = RCAP - CONST + VALCAP

14 CONTINOE

DTAX $=$ DTAX $*$ PD (N) *TAX

C

IF IDC IS TREATED AS BORROFED MONEY AND NOT CAPITALIZED, IT IS INCLODED WITH PRE-OPERATION COSTS IN ITEMIZATION

$A D P R E=A D P R E+(X P R E+X I D C) * P D(N)$

$A C A P=A C A P+C C A P * F D(I)$ 


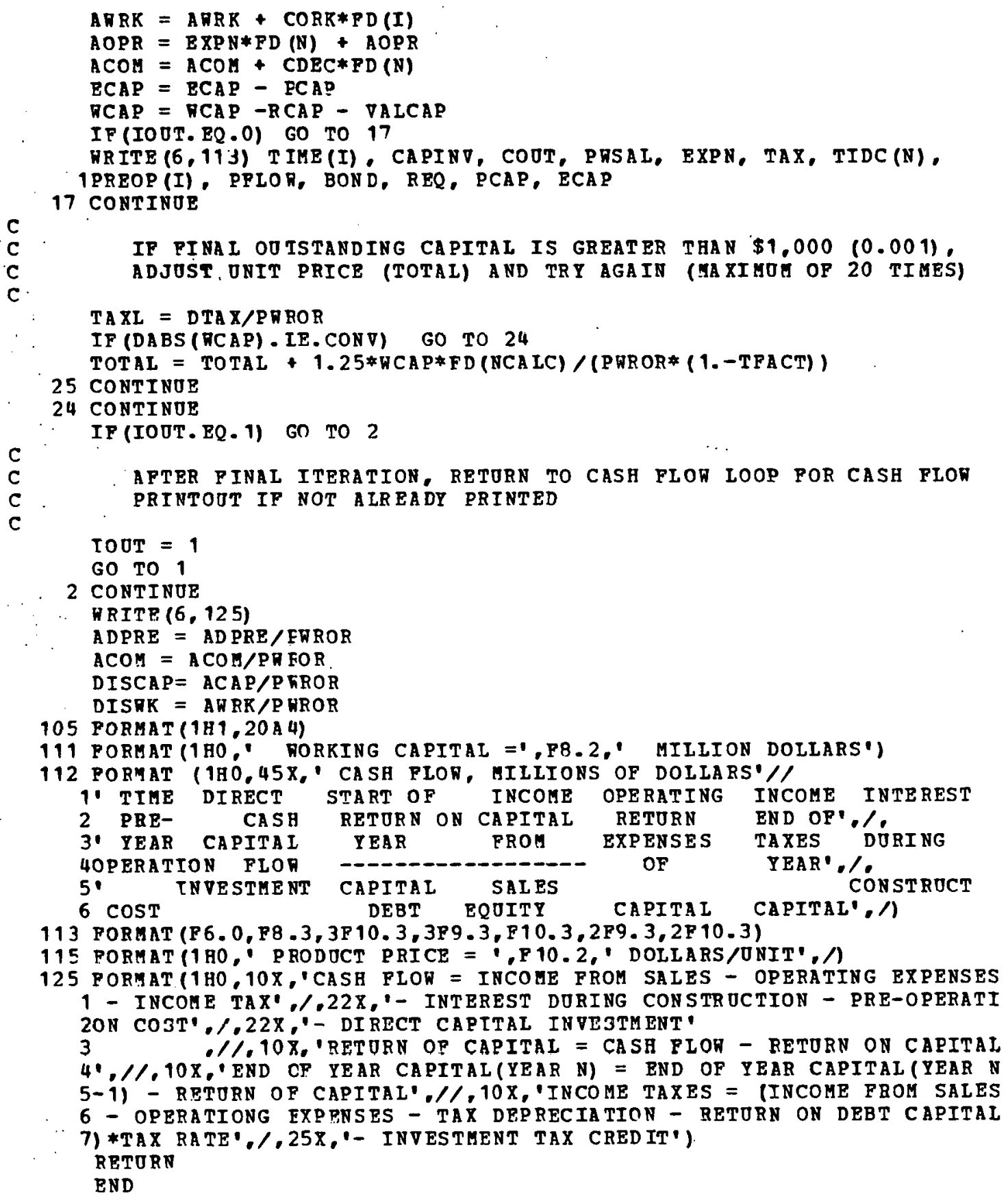




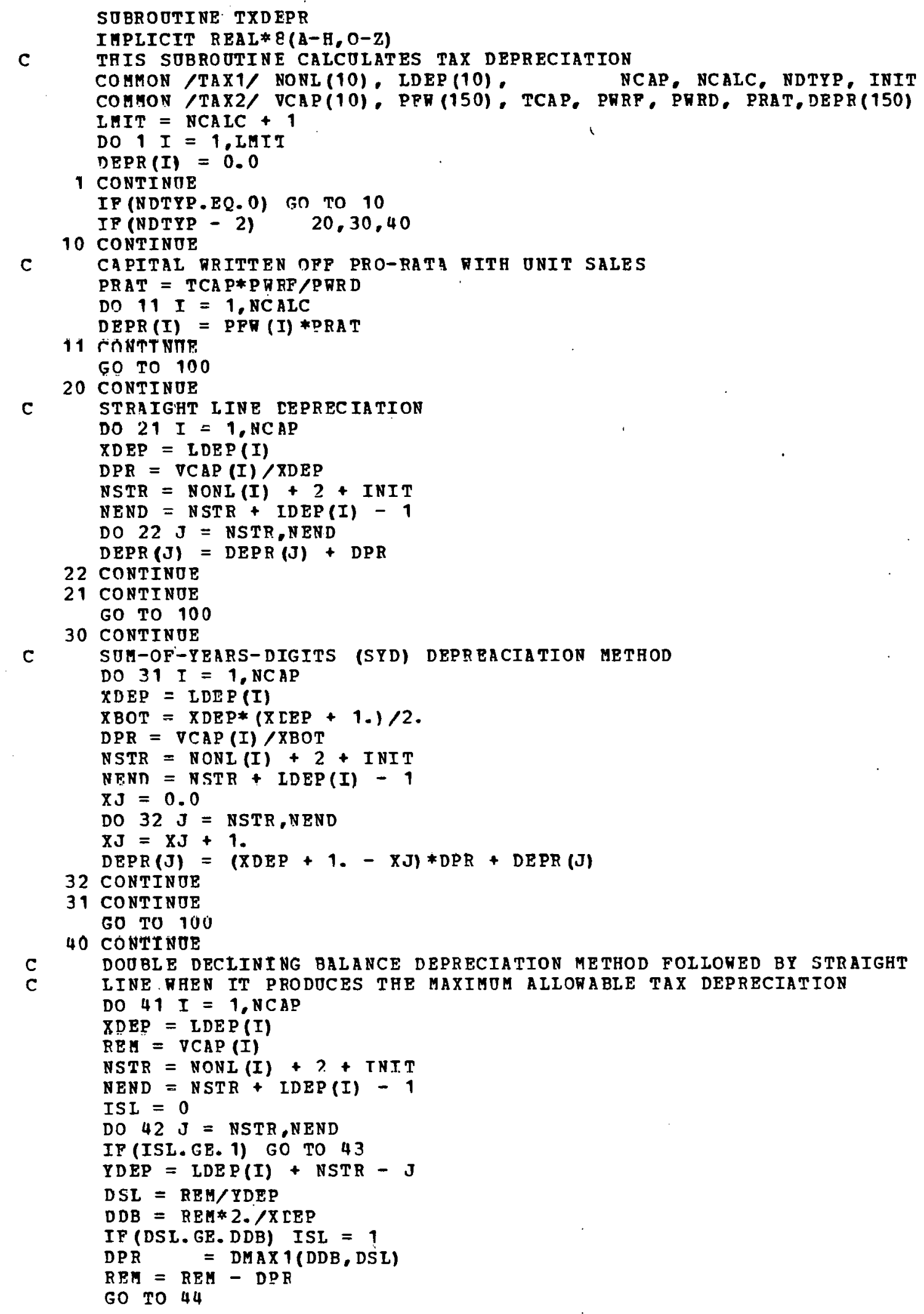


$43 \mathrm{DPR}=\mathrm{DSI}$

44 CONTINOE

$\operatorname{DEPR}(\mathrm{J})=\operatorname{DPR}+\operatorname{DEPR}(\mathrm{J})$

42 CONTINOE

41 CONTTNOE

100 CORTINOE

RETORH

END

$\mathrm{C}$
$\mathrm{C}$
$\mathrm{C}$

SUBROUTINE ZERC

SUBROOTINE ZERO SETS VARIODS VARIABLES TO ZERO TO INITIALIZE CASE

I PPLICIT REAL*8(A-H, O-Z)

COHKON/ZEROS/ ALL $(4800)$

COHMON/Z ERO2/ EALL (25)

DO $10 T=1,4800$

ALI (I) $=0.0$

10 CONTINOE

DO $20 I=1,25$

$\operatorname{BALL}(I)=0.0$

20 CONTINUE

RETORN

END 


\section{THIS PAGE}

WAS INTENTIONALLY

LEFT BLANK 
Append I $\mathrm{C}$ SAMPLE OUTPUT 


\section{THIS PAGE}

\section{WAS INTENTIONALLY \\ LEFT BLANK}




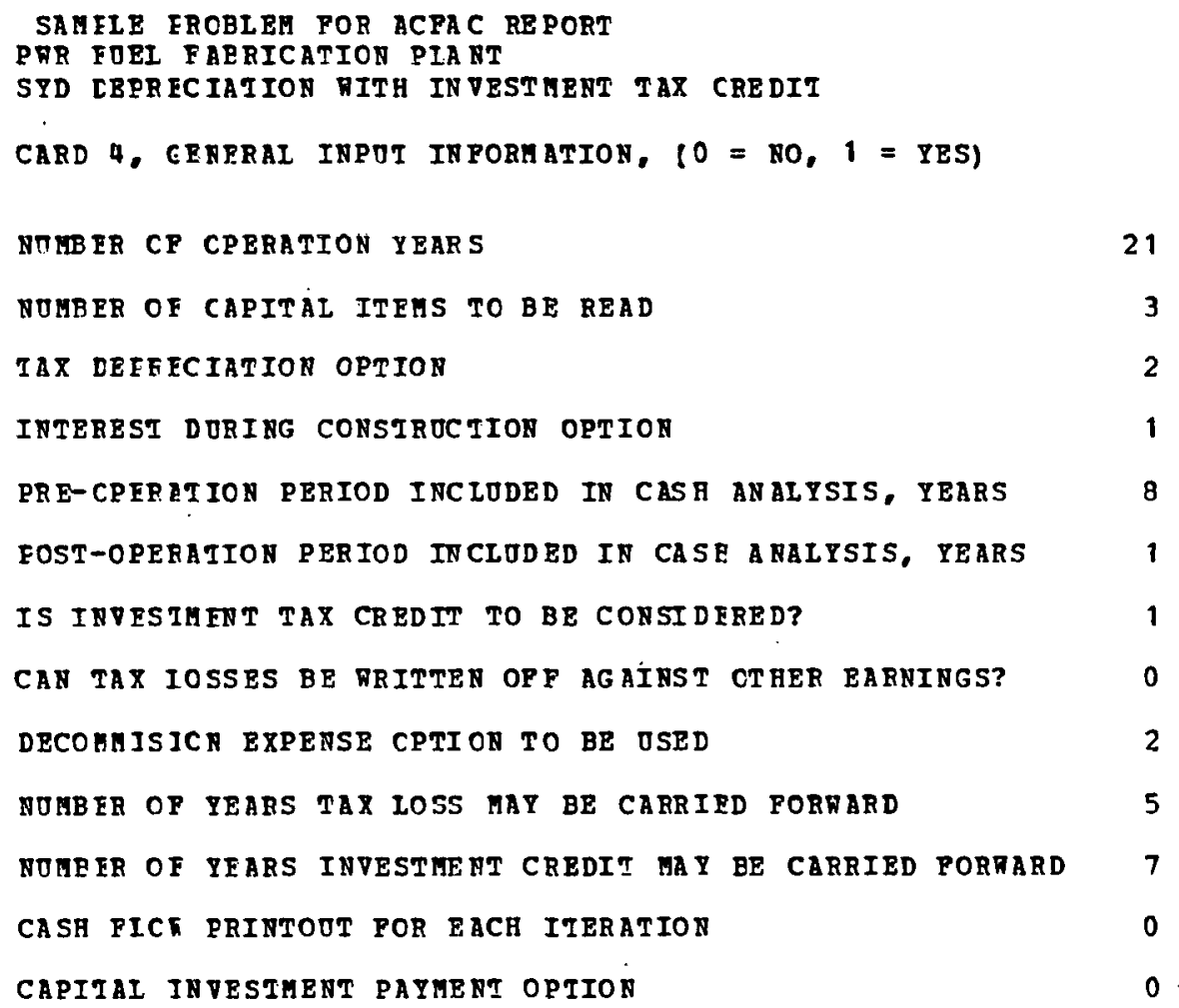




\begin{tabular}{|c|c|}
\hline RETOFN CN EQOITY INVESTMENT, FRACTION & 0.140 \\
\hline INTEREST RATE ON CAPITALIZED DEBT, FEACTION & 0.083 \\
\hline FRACTICN OF CAPITAIIZATICN FROM DEBT & 0.350 \\
\hline FEDRFAI INCOAE TAX RATE, FRACTION & $0.4 E 0$ \\
\hline STATE IRCC ME TAX RATE, PRACTION & 0.040 \\
\hline COST S ARF IN DOLLARS OP THIS YEAR & 1978.000 \\
\hline MAXIMOH FRACTION OF TAXES VAICH TAX CEEDIT CAN OPPSET & 0.500 \\
\hline CASH FTRD CONVRRGRNCE TOLERANCQE, HILIICCN\$ & 0.010 \\
\hline INPCT IRPCRMATION ON CARDS 6 AND 7 & \\
\hline MORKING CAEITAL, MILIION \$ & 9. 112 \\
\hline INTEEEST DORING CONSTROCTION & 0.105 \\
\hline PROPERTY TEX RATE & 0.025 \\
\hline INSTEARCE EAIE & 0.005 \\
\hline INTEFIH FEEI ACEMENT RATE & 0.010 \\
\hline CAPITAI VALOE POR INTERIM REPI. PORPOSES, MIIIION \$ & 34.200 \\
\hline CAPITAL EASE FOR INS. AND PROP. TAX, EIIIION $\$$ & 66.200. \\
\hline POLI PFCDOCTION RATE, ORITS/YEAR & 520000 \\
\hline TEAR EBODOCTION IS TO BEGIN & 1990. \\
\hline MATEFIAL CCST AT PULIL PRODUCTION, BILLIUN $\$ / Y \mathrm{BAR}$ & 23.049 \\
\hline OPERATICN COSI AT FOLL PRODUCTION, MIILICN \$/YEAR & 13. 383 \\
\hline FIXED CCST PRACTION CF OPERATION COST & 0.100 \\
\hline NPFRATTRG COST FRACTION PROPORTIOHAL TO PRODUCTION & 0.900 \\
\hline DECOHHISSICNING EXPENSE AS FRACTION OF SÄIES & 0.010 \\
\hline INTEEEST PAIL ON DECOMMI SSIONING EXPENSE ANNOYTY & 0.080 \\
\hline
\end{tabular}


CARD 8, CAFACITY PACTORS AND MISCELIAREOUS EXPENSES

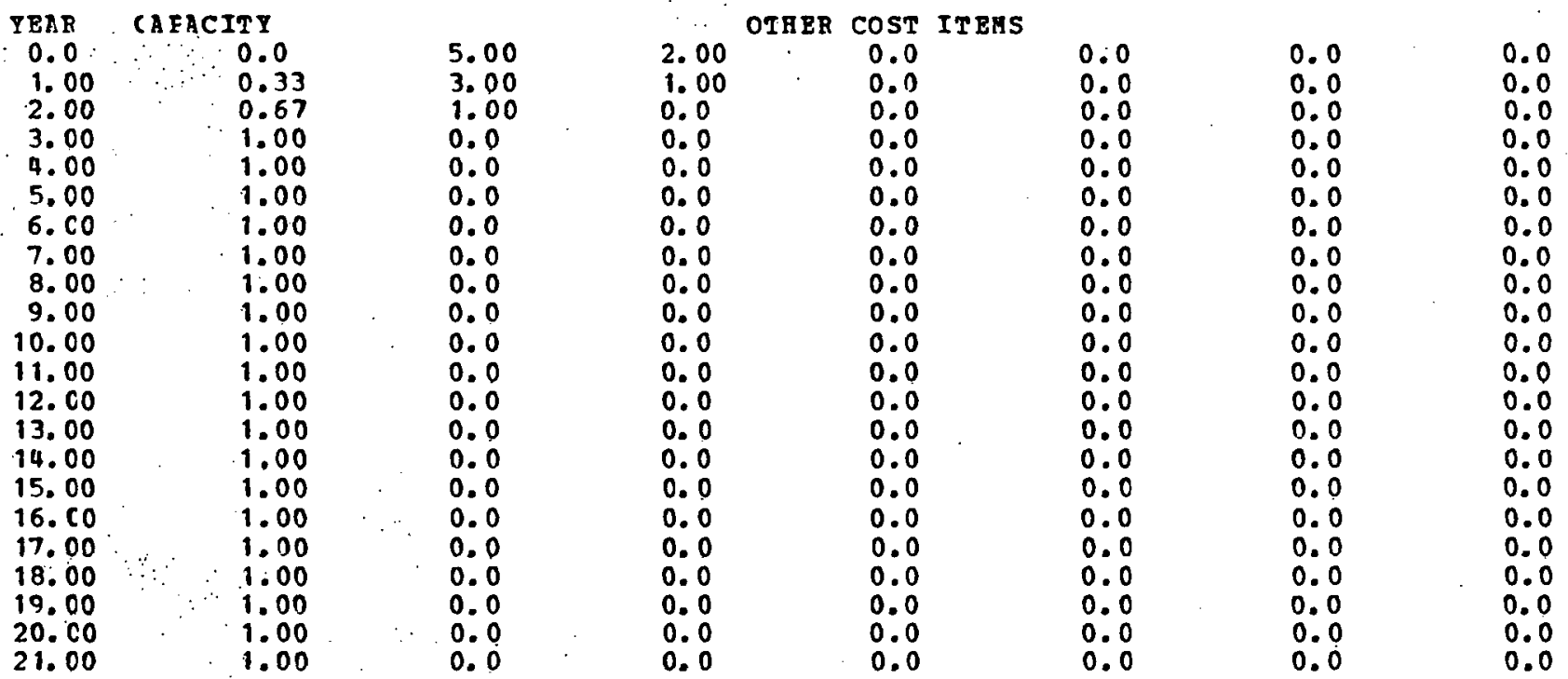




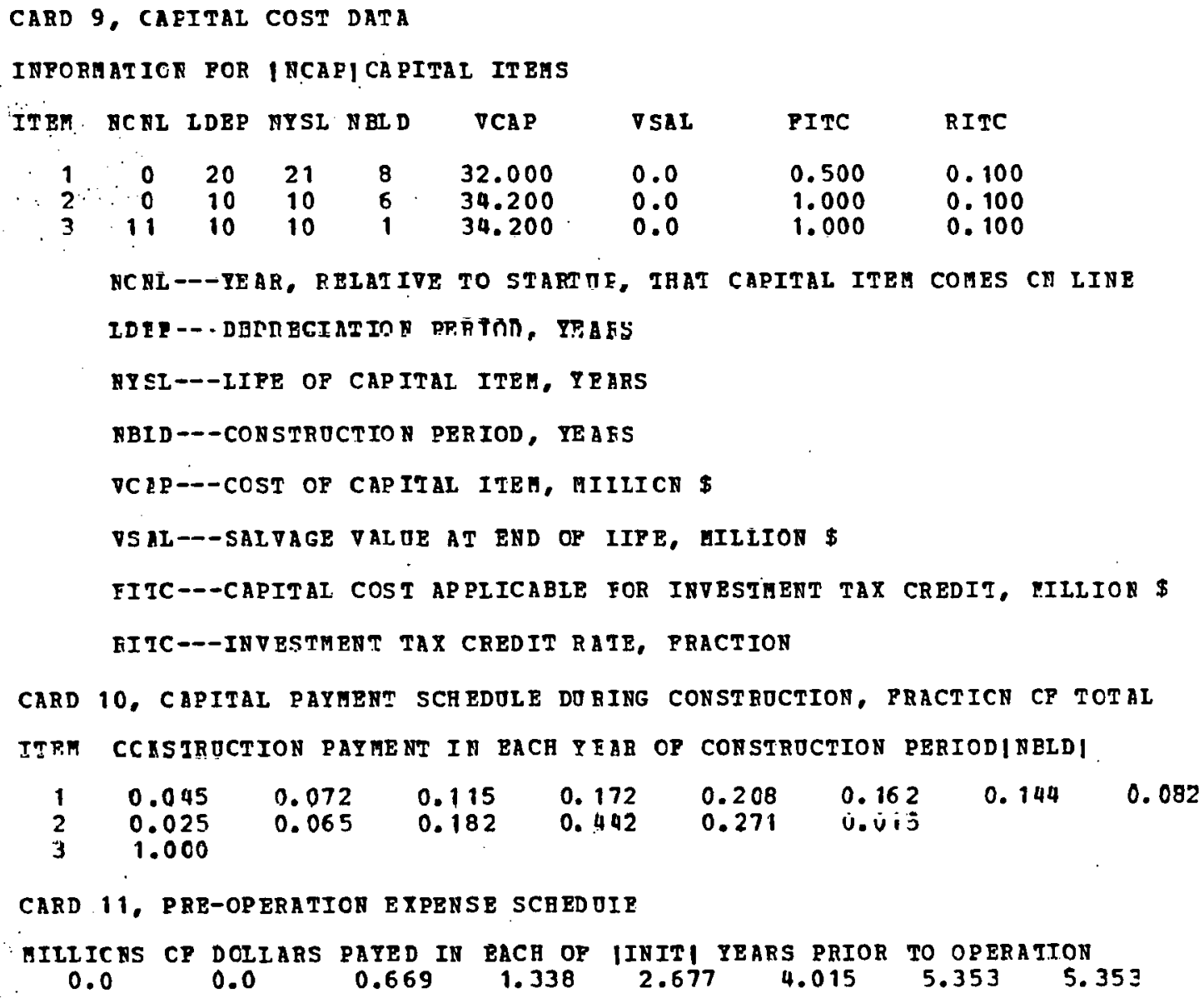


SCEEDOLE OP EXPENSES, MILIOHS OP DCLLARS

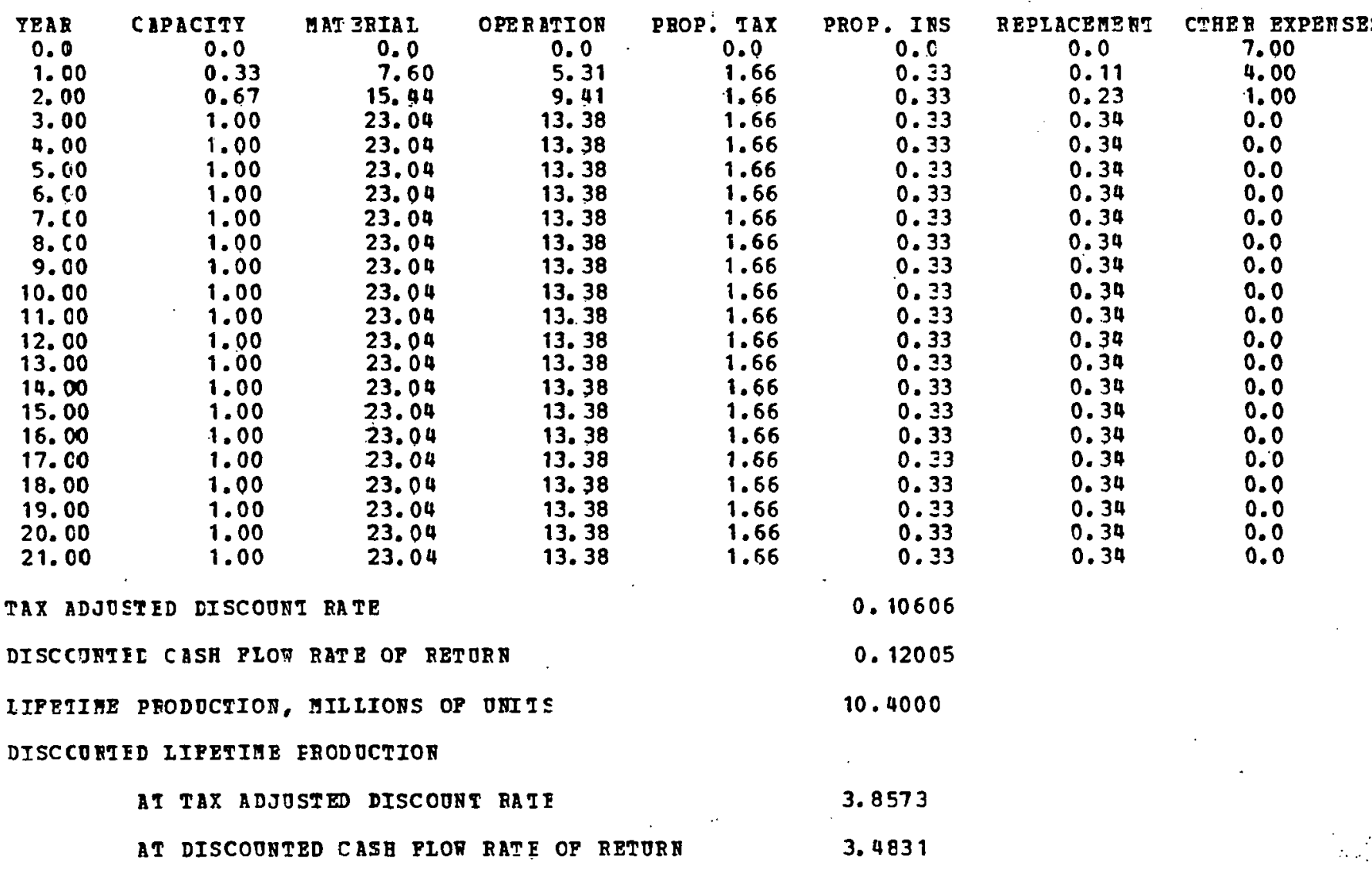


CAPITAI INVESTEENT CaSE PLOG, MEIIIO\& $\$$

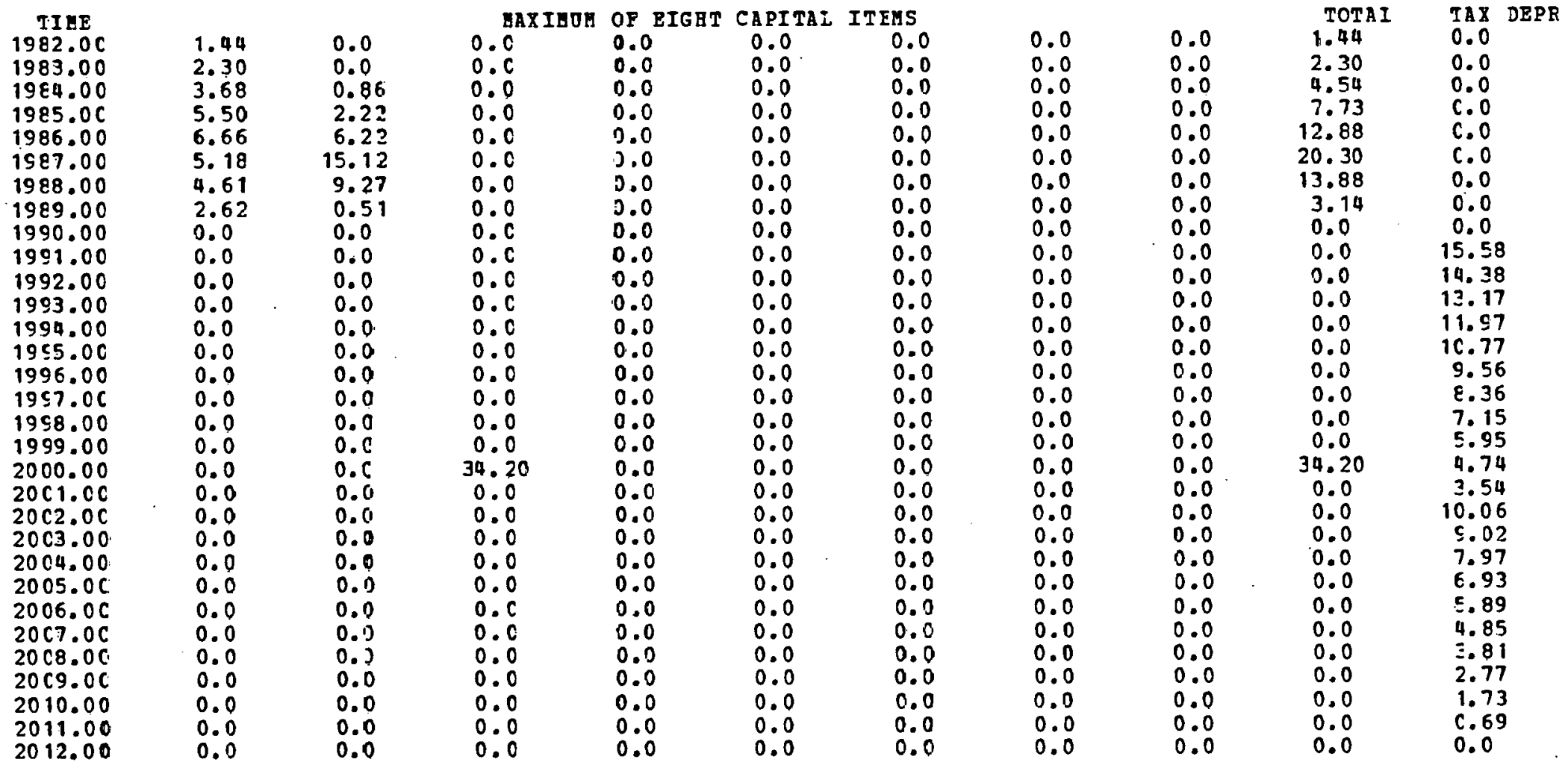


SAMEIE FRCBLEM FOR ACFAC REPORT

PRODOCT PEICE $=130.14$ DCLLARS/ORIT

FC ERING CAPITAL $=9.11$ EILIICR DCLIARS

CASH FLOR, MIIIIONS OF DCIIARS

\begin{tabular}{|c|c|c|c|c|c|c|c|c|c|c|c|c|}
\hline $\begin{array}{l}\text { TIME } \\
\text { YEAR } \\
\qquad\end{array}$ & $\begin{array}{c}\text { DIEBCT } \\
\text { CAFITAL } \\
\text { INVESTUENT }\end{array}$ & $\begin{array}{c}\text { STERT OZ } \\
\text { YBAR } \\
\text { CAPITAI }\end{array}$ & $\begin{array}{l}\text { I XCOAE } \\
\text { PRCM } \\
\text { SALES }\end{array}$ & $\begin{array}{l}\text { OPEBATIKG } \\
\text { EXERNSES }\end{array}$ & $\begin{array}{l}\text { INCOME } \\
\text { TAXES }\end{array}$ & $\begin{array}{l}\text { INTEREST } \\
\text { DTRING } \\
\text { CONSTRUCT }\end{array}$ & $\begin{array}{l}\text { PRE- } \\
\text { CPERATIOR } \\
\text { COST }\end{array}$ & $\begin{array}{l}\text { CASH } \\
\text { PIOA }\end{array}$ & $\begin{array}{c}\text { FETORN } 0 \\
\text { DEBT }\end{array}$ & $\begin{array}{l}\text { CAPITAL } \\
\text { BQOITY }\end{array}$ & $\begin{array}{l}\text { RET ORA } \\
\text { CF } \\
\text { CAPITAI }\end{array}$ & $\begin{array}{l}\text { END OF } \\
\text { PEAR } \\
\text { CAPITAL }\end{array}$ \\
\hline $\begin{array}{l}1982 . \\
1983 . \\
1984 . \\
1985 . \\
1986 . \\
1987 . \\
1988 . \\
1989 . \\
1990 . \\
1991 . \\
1992 . \\
1993 . \\
1994 . \\
1995 . \\
1996 . \\
1997 . \\
1998 . \\
1990^{\circ} . \\
2000 . \\
2001 . \\
2002 . \\
2003 . \\
2004 . \\
2005 . \\
2006 . \\
2007 . \\
2008 . \\
2009 . \\
2010 . \\
2011 . \\
2012 .\end{array}$ & 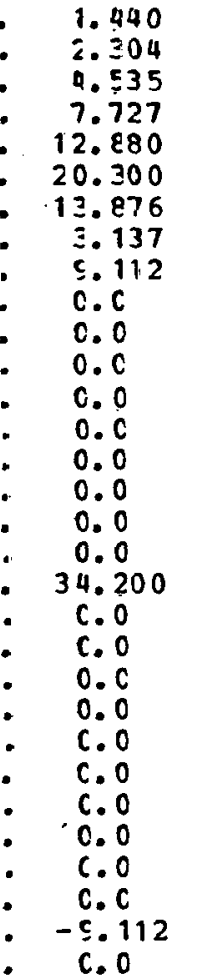 & $\begin{array}{r}1.440 \\
3.895 \\
8.839 \\
18.234 \\
34.507 \\
61.389 \\
86.147 \\
104.245 \\
137.218 \\
153.598 \\
151.851 \\
142.264 \\
131.586 \\
121.891 \\
112.230 \\
103.885 \\
96.817 \\
89.579 \\
116.354 \\
112.313 \\
101.445 \\
92.738 \\
86.092 \\
75.030 \\
65.5509 \\
55.479 \\
44.887 \\
33.673 \\
21.771 \\
-0.004 \\
-0.004\end{array}$ & $\begin{array}{l}0.0 \\
0.0 \\
0.0 \\
0.0 \\
0.0 \\
0.0 \\
0.0 \\
0.0 \\
22.332 \\
45.340 \\
67.672 \\
67.672 \\
67.672 \\
67.672 \\
67.672 \\
67.672 \\
67.672 \\
67.672 \\
67.672 \\
67.672 \\
67.672 \\
67.672 \\
67.672 \\
67.672 \\
67.672 \\
67.672 \\
67.672 \\
67.672 \\
67.672 \\
0.0 \\
0.0\end{array}$ & $\begin{array}{l}0.0 \\
0.0 \\
0.0 \\
0.0 \\
0.0 \\
0.0 \\
0.0 \\
7.000 \\
19.239 \\
28.514 \\
39.429 \\
39.429 \\
39.429 \\
39.429 \\
39.429 \\
39.429 \\
39.429 \\
39.429 \\
39.429 \\
39.429 \\
39.429 \\
39.429 \\
39.429 \\
39.429 \\
39.429 \\
39.429 \\
39.429 \\
39.429 \\
39.429 \\
0.0 \\
0.0\end{array}$ & $\begin{array}{l}0.0 \\
0.0 \\
0.0 \\
0.0 \\
0.0 \\
0.0 \\
0.0 \\
0.0 \\
0.0 \\
0.0 \\
0.426 \\
0.486 \\
2.751 \\
3.949 \\
6.425 \\
8.704 \\
9.383 \\
10.064 \\
10.748 \\
3.892 \\
7.357 \\
8.464 \\
9.086 \\
9.714 \\
10.349 \\
10.991 \\
11.640 \\
12.298 \\
12.966 \\
0.000 \\
0.000\end{array}$ & $\begin{array}{l}0.151 \\
0.409 \\
0.998 \\
2.055 \\
3.904 \\
6.867 \\
9.608 \\
11.508 \\
0.0 \\
0.0 \\
0.0 \\
0.0 \\
0.0 \\
0.0 \\
0.0 \\
0.0 \\
0.0 \\
0.0 \\
3.591 \\
0.0 \\
0.0 \\
0.0 \\
0.0 \\
0.0 \\
0.0 \\
0.0 \\
0.0 \\
0.0 \\
0.0 \\
0.0 \\
0.0\end{array}$ & $\begin{array}{l}0.0 \\
0.0 \\
0.069 \\
1.338 \\
2.077 \\
0.015 \\
5.353 \\
5.353 \\
0.0 \\
0.0 \\
0.0 \\
0.0 \\
0.0 \\
0.0 \\
0.0 \\
0.0 \\
0.0 \\
0.0 \\
0.0 \\
0.0 \\
0.0 \\
0.0 \\
0.0 \\
0.0 \\
0.0 \\
0.0 \\
0.0 \\
0.0 \\
0.0 \\
0.0 \\
0.0\end{array}$ & $\begin{array}{r}-1.591 \\
-2.713 \\
-6.202 \\
-11.120 \\
-19.462 \\
-31.183 \\
-28.837 \\
-26.998 \\
-6.019 \\
16.826 \\
27.817 \\
27.757 \\
25.492 \\
24.294 \\
21.818 \\
19.539 \\
18.860 \\
18.179 \\
-20.296 \\
24.351 \\
20.886 \\
19.779 \\
19.157 \\
18.529 \\
17.894 \\
17.252 \\
16.603 \\
15.944 \\
15.277 \\
9.112 \\
-0.000\end{array}$ & $\begin{array}{l}0.0 \\
0.0 \\
0.0 \\
0.0 \\
0.0 \\
0.0 \\
0.0 \\
0.0 \\
3.586 \\
4.375 \\
4.411 \\
4.133 \\
3.823 \\
3.541 \\
3.260 \\
3.018 \\
2.813 \\
2.602 \\
2.387 \\
3.263 \\
2.947 \\
2.694 \\
2.443 \\
2.180 \\
1.903 \\
1.612 \\
1.304 \\
0.978 \\
0.632 \\
-0.000 \\
-0.000\end{array}$ & $\begin{array}{l}0.0 \\
0.0 \\
0.0 \\
0.0 \\
0.0 \\
0.0 \\
0.0 \\
0.0 \\
12.487 \\
13.704 \\
13.818 \\
12.946 \\
11.974 \\
11.092 \\
10.213 \\
9.454 \\
8.810 \\
8.152 \\
7.476 \\
10.220 \\
9.232 \\
8.439 \\
7.652 \\
6.828 \\
5.961 \\
5.049 \\
4.085 \\
3.064 \\
1.981 \\
-0.000 \\
-0.000\end{array}$ & $\begin{array}{r}-1.591 \\
-2.713 \\
-6.202 \\
-11.120 \\
-19.462 \\
-31.183 \\
-28.837 \\
-26.598 \\
-22.492 \\
-1.254 \\
9.587 \\
10.678 \\
9.695 \\
5.651 \\
8.345 \\
7.068 \\
7.237 \\
7.425 \\
-30.159 \\
10.868 \\
8.708 \\
8.646 \\
9.062 \\
5.521 \\
10.030 \\
10.592 \\
11.214 \\
11.902 \\
12.663 \\
9.112 \\
0.000\end{array}$ & $\begin{array}{r}1.591 \\
4.304 \\
10.507 \\
21.627 \\
41.088 \\
72.271 \\
101.108 \\
128.106 \\
150.598 \\
151.851 \\
142.264 \\
131.586 \\
121.891 \\
112.230 \\
103.885 \\
96.817 \\
89.579 \\
82.154 \\
112.313 \\
101.445 \\
92.738 \\
84.092 \\
75.030 \\
65.509 \\
55.479 \\
44.887 \\
33.673 \\
21.771 \\
9.108 \\
-0.004 \\
-0.004\end{array}$ \\
\hline
\end{tabular}

CASH PLON = IN COME PROM SAIES - OPERATING EXPENSES - INCOME IAX

- I BTEREST DORIRG CCNSIROCIION - PRE-OPERAIION COST

- DIRECT CA PITAI INVESTHENT

GETURN OP CAPIT RL = CASA FLOR - RETURN ON CAPITAL

BND OF TEAR CAPITAL (YEAR M) = END OP TEAR CAPITAL (YEAB N-1) - RETORN CP CAPITAL

INCCAE TAXZS = IINCOHE FROM SAL ES - OPERATIORG EXPENSES - TAX DEPRECIAIION - REIORN ON DEBT CAEITAL) *TÁX RATE - INVESTHENT TAX CREDIT 


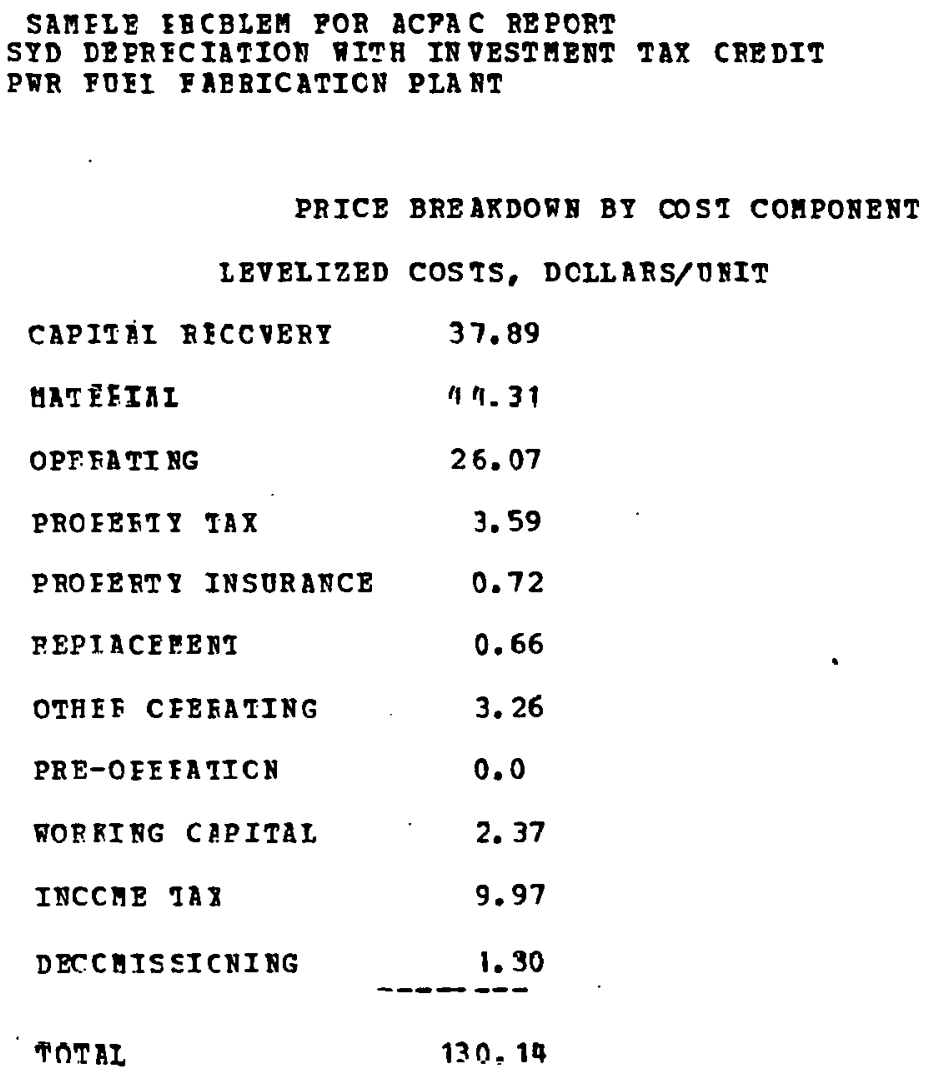

FINAL VAIDE OF ANNOTTY TO DECOHAISSICA PIANT - 


\section{Internal Distribution}

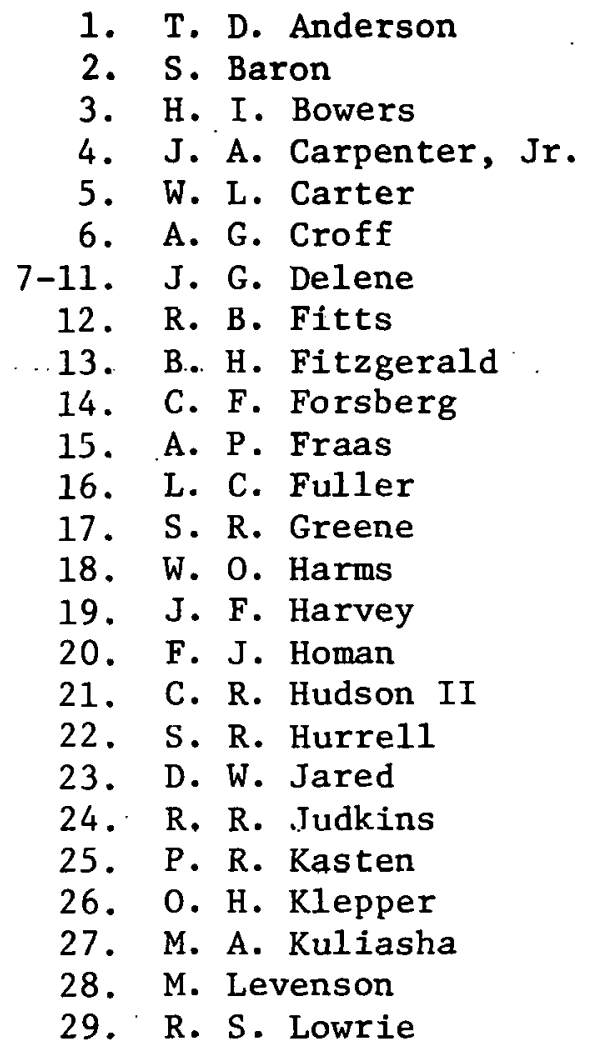

30. B. F. Maskewitz

31. S. R. McNeany

32. M. L. Myers

33. K. J. Notz

34. W. P. Poore

35. R. T. Primm

36. B. E. Prince

37. S. A. Reed

38. J. L. Rich

39. R. Salmon

40. D. Scott

41. G. R. Smolen

42. I. Spiewak

43. T. K. Stovall

44. H. E. Trammell

45. D. B. Trauger

46. W. F. Unger

47. J. E. Vath

48. W. C. Wright

49. ORNL Patent Office

50-51. Central Research Library

52. Document Reference Section

53-54. Laboratory Records Department

55. Laboratory Records, RC

\section{External Distribution}

56. Director, Office of Nuclear Energy Programs, Department of Energy, Washington, DC 20545

57. Offlce of Assistant Manager, Energy Research and Development, DOE, ORO

58. Director, Nuclear Research and Development Division, DOE, ORO

59. S. T. Brewer, Office of Nuclear Energy Programs, Department of Energy, Washington, DC 20545

60. M. W. Koehlinger, Office of Nuclear Energy Programs, Department of Energy, Washington, DC 20545

61. E. Delaney, Division of Nuclear Alternative Systems Assessment, Department of Energy, Washington, DC 20545

62. D, E. Mathes, Division of Nuclear Alternative Systems Assessment, Department of Energy, Washington, DC 20545

63. R. Beatty, Science Applications, Inc., 800 Oak Ridge Turnpike, Oak Ridge, TN 37830

64-198. For distribution as shown in DOE/TIC-4500 under category UC-80 (General Reactor Technology) 